\title{
Copper Studies for Alternative Salt Disposition
}

by

K. G. Brown

Westinghouse Savannah River Company

Savannah River Site

Aiken, South Carolina 29808

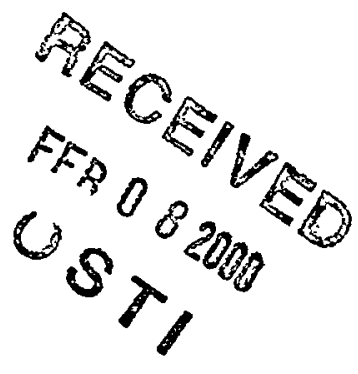

W. E. Daniel

This paper was prepared in connection with work done under the above contract number with the U.S. Department of Energy. By acceptance of this paper, the publisher and/or recipient acknowledges the U.S. Government's right to retain a nonexclusive, royalty-free license in and to any copyright covering this paper, along with the right to reproduce and to authorize others to reproduce all or part of the copyrighted paper. 


\section{DISCLAIMER}

This report was prepared as an account of work sponsored by an agency of the United States Government. Neither the United States Government nor any agency thereof, nor any of their employees, makes any warranty, express or implied, or assumes any legal liability or responsibility for the accuracy, completeness, or usefulness of any information, apparatus, product or process disclosed, or represents that its use would not infringe privately owned rights. Reference herein to any specific commercial product, process or service by trade name, trademark, manufacturer, or otherwise does not necessarily constitute or imply its endorsement, recommendation, or favoring by the United States Government or any. agency thereof. The views and opinions of authors expressed herein do not necessarily state or reflect those of the United States Government or any agency thereof.

This report has been reproduced directly from the best available copy.

Available for sale to the public, in paper, from: U.S. Department of Commerce, National Technical Information Service, 5285 Port Royàl Road, Springfield, VA 22161

phone: (800) 553-6847

fax: (703) 605-6900

. email: orders@ntis.fedworld.gov

online ordering: http://www.ntis.gov/ordering.htm

Available electronically at http://www.doe.gov/bridge . .

Available for a processing fee to U.S. Department of Energy and its contractors, in paper, from: U.S. Department of Energy, Office of Scientific and Technical Information, P.O. Box 62, Oak Ridge, TN 37831-0062

phone: (865)576-8401

fax: (865)576-5728

email: reports@adonis.osti.gov . 


\section{DISCLAIMER}

This report was prepared by Westinghouse Savannah River Company (WSRC) for the United States Department of Energy under Contract No. DE-AC0989SR18035 and is an account of work performed under that contract. Neither the United States Department of Energy, not WSRC, nor any of their employee makes any warranty, expresses or implied, assumes any legal liability or responsibility for accuracy, completeness, or usefulness, of any information, apparatus, or product or process disclosed herein or represents that its use will not infringe privately owned rights. Reference herein to any specific commercial product, process, or service by trademark, name, manufacturer or otherwise does not necessarily constitute or imply endorsement, recommendation, or favoring of same by WSRC or by the United States Government or any agency thereof. The views and opinions of the authors expressed herein do not necessarily state or reflect those of the United States Government or any agency thereof. 


\section{DISCLAIMER}

Portions of this document may be illegible in electronic image products. Images are produced from the best available original document. 
Keywords: DWPF, Copper, PCT, REDOX, Deposition

Retention: Permanent

\section{Copper Studies for Alternative Salt Disposition (U)}

K. G. Brown

W. E. Daniel

Publication Date: July 1, 1999

Westinghouse Savannah River Company

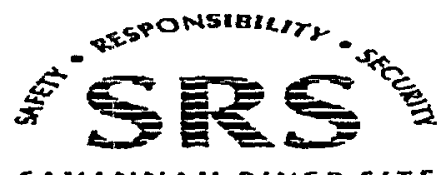

PREPARED FOR THE U.S. DERARTMENT OF ENERGY UNDER CONTRACT NO, DE-AC09-96SR18500 


\section{Approvals}

$4{ }^{-} O R=$

K. G. Brown, Author

Q. ₹ Samer

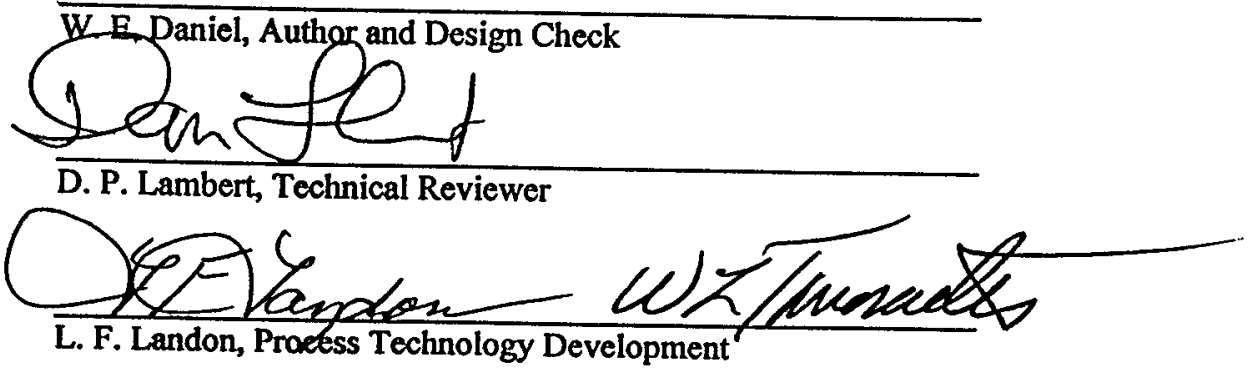

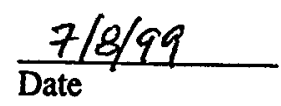

$\frac{7 / 8 / 99}{\text { Date }}$

$7 / 8 / 99$

Date

$\frac{7 / 8 / 99}{\text { Date }}$

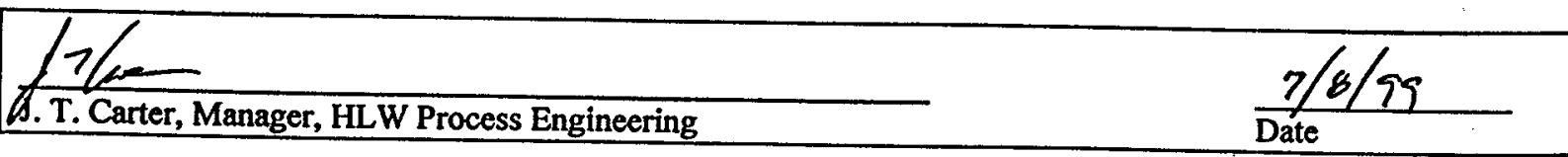




\section{EXECUTIVE SUMMARY}

The solubility of copper in borosilicate glass is dependent upon both the total copper concentration and the glass REDuction-OXidation (REDOX) state. Iron REDOX (i.e., $\mathrm{Fe}^{2+} / \Sigma \mathrm{Fe}$ ) was shown by previous researchers to be a reliable indicator of the overall REDOX state of a DWPF glass. Schumacher and Ramsey demonstrated experimentally that metallic copper will precipitate out of simulated DWPF waste glass under reducing conditions when the total copper concentration is approximately $0.5 \% \mathrm{Cu}$ in glass and REDOX greater than 0.07. The precipitated, metallic copper has potential to (1) deleteriously affect the durability of the glass and (2) shorten the melter lifetime (by collecting on the melter bottom and creating an electrical short or perhaps by alloying with the Inconel electrodes and causing erosion). Consequently, the current DWPF limit in the Product Composition Control System (PCCS) is $0.5 \mathrm{wt} \% \mathrm{Cu}$ (although this limit may need to be decreased based upon more recent findings).

The purpose of this study is to determine, as functions of total copper loading and iron REDOX in glass, any dependence of the leaching behavior of borosilicate glass on metallic copper. Glasses were fabricated incorporating 0.5 to over $1.0 \mathrm{wt} \%$ total copper in glass at varying iron REDOX ratios. These glasses span the acceptable DWPF range for iron REDOX.

Three of the resulting glasses were selected based upon visual appearance: one was black and shiny and the other two had copious, visible metallic copper present (i.e., brown streaks). These three glasses were analyzed for iron REDOX and leaching behavior based upon the Product Consistency Test (PCT). The data indicate that the presence of precipitated, metallic copper does not negatively impact glass durability. Visual examinations of the glasses made in this study (which included those more reducing than expected in DWPF) indicated that metallic copper did not appear to collect on the crucible bottoms which provides some reassurance that metallic copper may not deleteriously impact DWPF melter life. However, it is recommended that at least a small-scale melter run be made to confirm these findings. Furthermore, composition measurements should be made to assure that no gross batching errors occurred as well as additional REDOX ratio and PCT responses to validate the measurements made. These results will make the conclusions of this study much more definitive. 


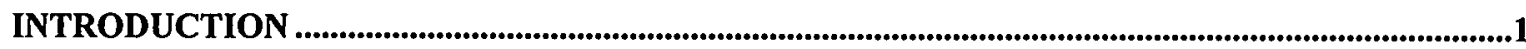

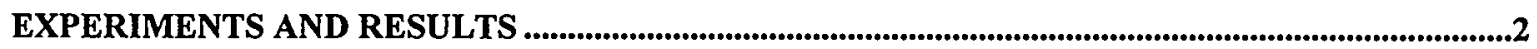

Metallic Copper Settling in the Crucible Studies....................................................................................................9

Targeted Versus Measured Values ........................................................................................................................12

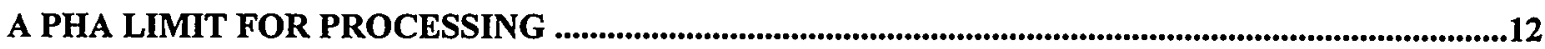

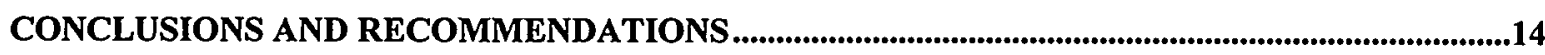

REFERENCES

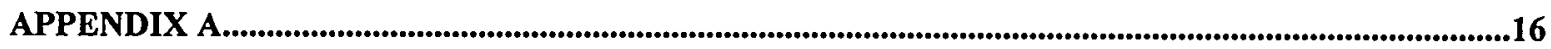

APPENDIX B

\section{LIST OF ILLUSTRATIONS}

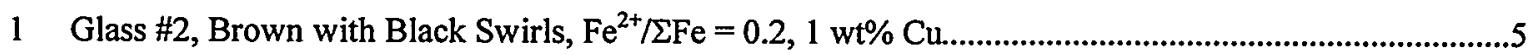

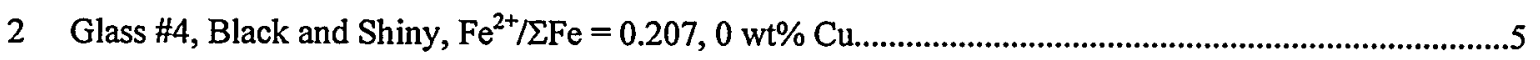

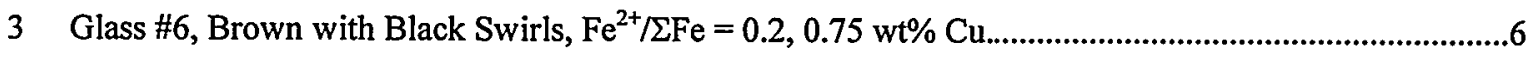

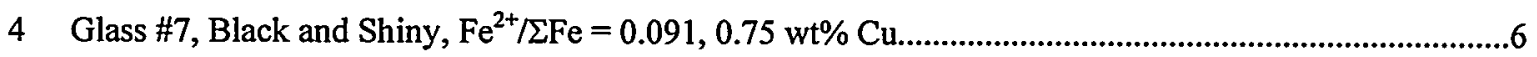

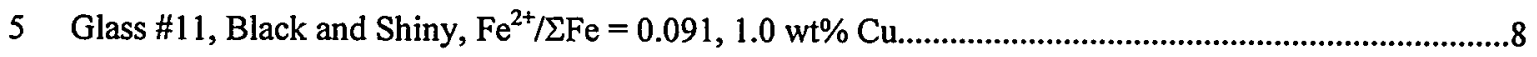

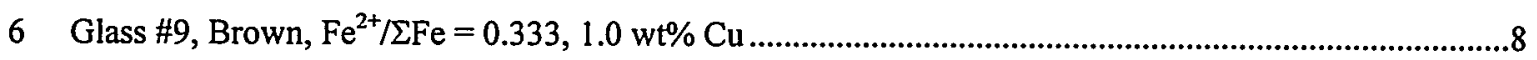

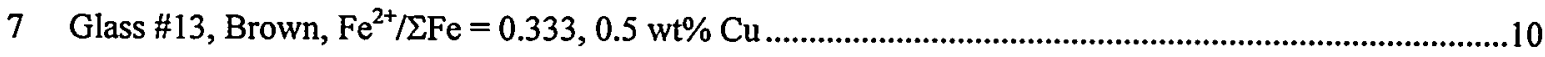

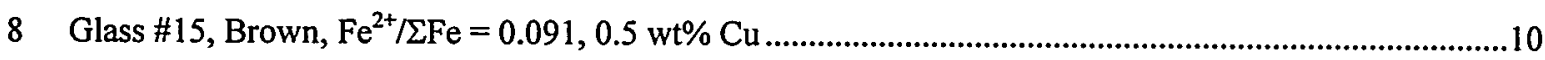

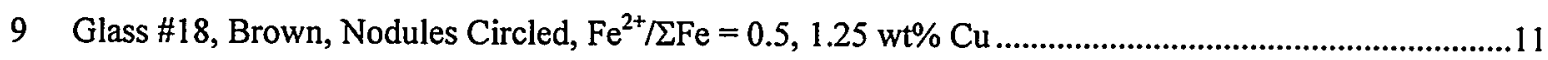

10 Glass \#20, Black Interface, Brown Middle, Nodules Circled, $\mathrm{Fe}^{2+} / \Sigma \mathrm{Fe}=0.5,1.0 \mathrm{wt} \% \mathrm{Cu} \ldots \ldots \ldots \ldots \ldots \ldots \ldots . . . . . .11$

\section{LIST OF TABLES}

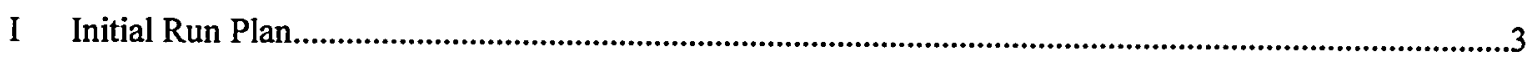

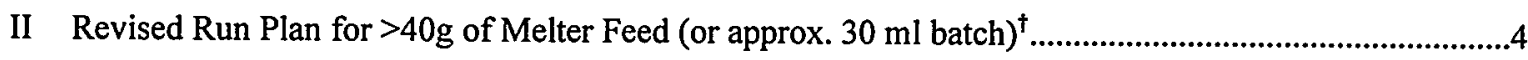

III REDOX and PCT Measurements for Glasses \#9, 10, and 11.......................................................

IV Summary of Crucible Runs for Salt Disposition Copper Studies............................................................13 


\section{INTRODUCTION}

With the advent of the precipitation process for cesium and strontium removal from DWPF wastes [1], the addition of a copper catalyst was found necessary to catalyze the decomposition of tetraphenylborate (TPB) at lower temperatures since the original process was going to be high temperature and pressure [2]. The solubility of copper in borosilicate glass is dependent upon both the total copper concentration and the overall REDuctionOXidation (REDOX) state of the glass. Iron REDOX (i.e., $\mathrm{Fe}^{2+} / \Sigma \mathrm{Fe}$ ) was shown by Schreiber to be a reliable indicator of the overall REDOX state of a DWPF glass [3].

Historically it has been demonstrated that metallic copper will precipitate out of simulated DWPF waste glass melts under reducing conditions when the total copper concentration is greater than approximately $0.5 \% \mathrm{Cu}$ and REDOX greater than 0.07 in glass [4,5]. Precipitated, metallic copper, which normally appears as brown streaks, has the potential to (1) deleteriously affect the durability of the glass (or its prediction) and/or (2) shorten the melter lifetime (by collecting on the melter bottom and creating an electrical short short or perhaps by alloying with the Inconel electrodes and causing erosion [6]). Consequently, there is currently a limit in the DWPF Product Composition Control System (PCCS) at $0.5 \mathrm{wt} \%$ total $\mathrm{Cu}$ [7] in glass.

With the proposed "Small Tank ITP" process, the product TPB slurry will not undergo a final wash, i.e. Late Wash. Previous hydrolysis studies have demonstrated that the lack of a final wash tends to drive the need for a greater copper catalyst requirement to produce an acceptable aqueous product, presumably due to a soluble radiolysis product that mitigates the effectiveness of the copper catalyst. A copper catalyst requirement of 1600 ppm was required to effectively hydrolyze a TPB slurry that had received an absorbed dose of 200 Mrad but had not undergone a final wash. With a final wash, the catalyst requirement was $475 \mathrm{ppm}$.

Although the product slurry from the "Small Tank TPB" process will receive significantly less absorbed dose, the concern was raised that the current copper limit in glass $(0.5 \mathrm{wt} \%)$ will be too restrictive to produce an acceptable aqueous product during hydrolysis. The bases for this concern are as follows:

- The lack of a final wash of the TPB slurry prior to hydrolysis

- Doubling of the aqueous product solids content in the glass product

- The desire to produce a melter feed more reducing that that which served as the basis for the $\mathbf{0 . 5}$ wt $\%$ copper limit

Calculations suggest that if the copper limit could be raised to $1.0 \mathrm{wt} \%$ in glass, the corresponding catalyst requirement during hydrolysis (1600 to $1900 \mathrm{ppm}$ ) would likely be adequate to produce an acceptable aqueous product. Consequently, it was recommended that a scoping study be performed assessing the impact on glass durability and metallic copper production over a copper range of $0.50 \mathrm{wt} \%$ to $1.0 \mathrm{wt} \%$ and over a REDOX range (i.e., $\mathrm{Fe}^{2+} / \Sigma \mathrm{Fe}$ ) of 0.09 to 0.33 .

The main purpose of this study is to estimate, as functions of total copper concentration and iron REDOX, any dependence of the leaching behavior (as indicated by durability) of borosilicate glass on metallic copper. A secondary task is to provide some qualitative evidence as to whether there is a tendency for the metallic copper to settle in the crucible melt. Glasses were fabricated from feeds incorporating approximately 0.5 to over 1.0 wt $\%$ total copper in glass at varying targeted iron REDOX ratios. These glasses were made to span the acceptable DWPF range of $0.09 \leq \mathrm{Fe}^{2+} / \Sigma \mathrm{Fe} \leq 0.33$ for iron REDOX [8]. Glasses with REDOX ratios below 0.09 may foam and accelerate refractory corrosion; whereas, those with REDOX ratios greater than 0.33 may experience metallic nickel and nickel sulfide formation and deposition. These conditions, therefore, represent significant operational and/or melter life concerns for DWPF and must be examined prior to going to higher total copper concentrations in DWPF glass.

Three of the resulting glasses with a targeted, total copper concentration of $1 \mathrm{wt} \%$ in glass were selected based upon visual appearance. One of the glasses was oxidized and, thus, black and shiny. The other two glasses were much more reduced and exhibited copious, visible metallic copper. These three glasses were analyzed for iron REDOX [9] and leaching behavior using the Product Consistency Test (PCT) [10]. The data indicate that the presence of precipitated, metallic copper does not negatively impact glass durability. Visual examinations of the 
glasses made in this study containing up to $1 \mathrm{wt} \%$ total $\mathrm{Cu}$ in glass (and which included those significantly more reduced than those expected in DWPF) indicated that metallic copper did not appear to collect on the crucible bottoms, even at much longer melt times than required for REDOX determination. This evidence provides some reassurance that metallic copper may not deleteriously impact DWPF melter life. However, these experiments cannot duplicate the feeding and idling of a melter over a period of years so $\mathrm{Cu}$ deposition cannot be ruled out completely.

\section{EXPERIMENTS AND RESULTS}

Originally, it was intended that the SRTC GTOP procedure [11] for REDOX vitrification be used directly to fabricate glasses for this study. C. M. Jantzen, who originally wrote the procedure, demonstrated it for the engineers and technicians participating in the study. A. D. Cozzi and R. F. Schumacher, who have also done extensive research in glass REDOX testing, were consulted prior to the beginning of testing. Based upon all information provided, it was discovered that a number of minor changes were necessary so that the glasses necessary for these tests could be provided. The final process was to dry the crucibles of about 40 grams of SME product for 3 hours at $90^{\circ} \mathrm{C}$, since sucrose was being used as the reducing agent. If formic acid is used then a lower drying temperature like $70^{\circ} \mathrm{C}$ must be used since formic acid has a boiling point similar to that of water. After drying, the crucibles were sealed with lids using nepheline gel and cured for 1 hour at $90^{\circ} \mathrm{C}$. After curing, the crucibles were placed into a pre-heated $1150^{\circ} \mathrm{C}$ oven and baked for 1 hour. Initially upon placing the $90^{\circ} \mathrm{C}$ crucibles into the $1150^{\circ} \mathrm{C}$ oven, the crucible lids would pop up and back down before the nepheline seal vitrified. Attempts were made to eliminate the popping by increasing the drying time and temperature but the final conditions stated earlier were chosen after consulting with $\mathrm{C}$. M. Jantzen. It is believed the popping is due to rapidly expanding air trapped in the $90^{\circ} \mathrm{C}$ crucible and cannot be eliminated unless the crucibles are evacuated while drying. After initial examination of glasses made, the popping did not matter as long as the crucible resealed itself. Other details concerning the experiment are provided in the appropriate laboratory notebook [12].

Since the concentration of metallic copper (as evidenced by brown streaks) in glass depends upon the total copper concentration and REDOX, a limit on the maximum total copper concentration in glass has been set because of suspected, possible deleterious effects of metallic copper on important glass properties like durability. During Qualification Runs and initial sludge-only radioactive operation, the limit on total copper did not present a serious operational constraint. However, because of the kinetics in the proposed Small-Batch ITP Alternative for Salt Disposition, much more copper may have to be added during precipitate processing than originally intended; this increased copper addition may correspond to as much as $1 \mathrm{wt} \%$ total $\mathrm{Cu}$ in the resulting glass product. Copper is higher because it may be higher in the PHA and the PHA loading in the glass will be higher. This is considerably higher than any limit previously set for maximum copper concentration in DWPF glass [13]. However, since no one has yet proven that metallic copper has a deleterious impact on DWPF glass properties or has a tendency to settle, this study was designed to provide an indication of potential difficulties from increased copper concentrations in glass.

The original study design is provided in Table I. The original feed material had a density $(\rho)$ of $1.3 \mathrm{~g} / \mathrm{ml}$, total weight percent solids ( $\omega)$ of $47 \%$, calcined solids (c) of approximately $40 \%$, and a predicted REDOX of 0.217 . The original feed contained no copper and was doped with copper nitrate, $\mathrm{Cu}\left(\mathrm{NO}_{3}\right)_{2}$, to three copper levels (i.e., $0.5,0.75$ and $1.0 \mathrm{wt} \%$ ) and sucrose, $\mathrm{C}_{12} \mathrm{H}_{22} \mathrm{O}_{11}$, and nitric acid to three REDOX values (i.e., $0.091,0.2$, and 0.333). For the first four tests (which were labeled \#1 through $\# 4$ as indicated in Table 1 ), approximately 30 grams of melter feed was initially added to each $100 \mathrm{ml}$ alumina crucible. Then the necessary quantities of $\mathrm{Cu}\left(\mathrm{NO}_{3}\right)_{2}$, sucrose, and nitric acid were weighed out and added corresponding to the desired target REDOX ratio (or $\mathrm{Fe}^{2+} / \Sigma \mathrm{Fe}$ ) and total $\mathrm{wt} \% \mathrm{Cu}$ in glass. ${ }^{1}$ The resulting melter feeds were then dried to tackiness in an oven at temperatures between 70 and $90^{\circ} \mathrm{C}$. The crucibles were then sealed using a nepheline gel and then the seals were cured for another hour at $90^{\circ} \mathrm{C}$. After curing the four crucibles were placed in a preheated furnace (at $1150^{\circ} \mathrm{C}$ ) for one hour for vitrification. After one hour, the crucibles were removed, the seals checked for integrity, and finally allowed to air cool. The glass was then broken out of the crucibles for examination for brown glass.

1 Appendix A provides the algorithm for computing the necessary quantities ofCu( $\left(\mathrm{NO}_{3}\right)_{2}$, sucrose, and nitric acid corresponding to specified REDOX ratio and total $\mathrm{wt} \% \mathrm{Cu}$ in glass. 
WRSC-TR-99-00222, Rev. 0

Table I. Initial Run Plan

(Assuming a 30g initial charge of melter feed, $\rho=1.314, \omega=47.09 \%, c \approx 40 \%$.)

\begin{tabular}{|c|c|c|c|c|c|c|}
\hline$\#$ & $\begin{array}{c}\text { Target } \\
\mathrm{Fe}^{2+} / \Sigma \mathrm{Fe}\end{array}$ & $\begin{array}{c}\text { Target } \\
\text { wt\% Cu }\end{array}$ & $\begin{array}{c}\mathrm{Cu}\left(\mathrm{NO}_{3}\right)_{2}{ }^{\dagger} \\
\text { grams }\end{array}$ & $\begin{array}{c}\text { Sucrose }^{\text {tf }} \\
\text { grams }\end{array}$ & $\begin{array}{c}50 \% \mathrm{HNO}_{3} \\
\text { grams }\end{array}$ & $\begin{array}{c}\text { Final } \\
\text { wt } \% \mathrm{Fe}\end{array}$ \\
\hline $4,8,12$ & 0.207 & 0.0 & - & -- & -- & 6.95 \\
\hline 1 & 0.333 & \multirow{3}{*}{1.0} & \multirow{3}{*}{0.462} & 0.333 & -- & \multirow{3}{*}{6.863} \\
\hline 2 & 0.2 & & & 0.15 & -- & \\
\hline 3 & 0.091 & & & -- & .. & \\
\hline 5 & 0.333 & \multirow{3}{*}{0.75} & & 0.292 & -- & \multirow{3}{*}{6.885} \\
\hline 6 & 0.2 & & 0.345 & 0.11 & -- & \\
\hline 7 & 0.091 & & & -- & $0.118^{\S}$ & \\
\hline 9 & 0.333 & \multirow{3}{*}{0.5} & & 0.252 & - & \multirow{3}{*}{6.906} \\
\hline 10 & 0.2 & & 0.23 & 0.07 & -- & \\
\hline 11 & 0.091 & & & -- & $0.24^{8 \S}$ & \\
\hline
\end{tabular}

+ The chemical formula for this compound is given as $\mathrm{Cu}\left(\mathrm{NO}_{3}\right)_{2} \cdot 3 \mathrm{H}_{2} \mathrm{O}$. The nitrate contribution from this compound is accounted for in the $\mathrm{Fe}^{2+} / \Sigma \mathrm{Fe}$ prediction; the volume contribution is assumed to be negligible.

it The chemical formula for sucrose is $\mathrm{C}_{12} \mathrm{H}_{22} \mathrm{O}_{11}$. The volume contribution from sucrose is assumed to be negligible.

¥ The total, measured iron concentration in the starting material is 6.95 grams $/ 100$ grams glass.

\# The addition of nitric acid necessary for this particular run both insignificant and smaller than can be reliably added).

8 This is assumed to be a $50 \%$ (or $10.35 \mathrm{M}$ ) nitric acid solution with $\rho=1.3043$. The mass provided will supply $9.625 \times 10^{-4}$ moles of $\mathrm{HNO}_{3}$.

$\S \S$ This is assumed to be a $50 \%$ (or $10.35 \mathrm{M}$ ) nitric acid solution with $\rho=1.3043$. The mass provided will supply $1.915 \times 10^{-3}$ moles of $\mathrm{HNO}_{3}$.

The visual results for the first four glasses (i.e., \#1 through \#4 as indicated in Table I) agreed with the results of earlier studies. Glasses \#1 and \#2, both of which were fabricated to contain $1 \mathrm{wt} \% \mathrm{Cu}$ in glass, at REDOX ratios of 0.333 and 0.2 , respectively were both brown with black swirls indicating copious amounts of metallic copper. An image of Glass \#2 is shown in Figure 1. If any visual anomalies like deposits, streaks, or specs were observed in the glass they are annotated in the figures. Glass \#3, which also was targeted to contain $1 \mathrm{wt} \%$ total $\mathrm{Cu}$ in glass, and Glass \#4, to which no copper was added, were targeted to be at the oxidized end of the acceptable range for DWPF (i.e., $\mathrm{Fe}^{2+} / \Sigma \mathrm{Fe}=0.091$ ). Both of these glasses were black and shiny as evidenced in Figure 2 for Glass \#4. These results indicated that the procedure was being executed properly and that sucrose appeared to provide predictable reduction; however, it was also obvious from these results that insufficient glass (i.e., approximately 12.75 grams) was produced from the 30 grams of melter feed for the REDOX and durability analyses that would be ultimately required. Therefore, the remainder of the tests were performed using more melter feed material.

Table II illustrates the revised design for the remaining tests using approximately 40 grams of melter feed per crucible. In these tests, the researcher did not attempt to obtain the exact amount of melter feed specified (e.g., in Table II) as attempting to add small quantities of melter feed historically has significantly altered the weight percent solids of the material being vitrified. This has, resulted in unexpected results. Using the same procedure (except using approximately 40 grams of melter feed per crucible), ${ }^{2}$ Glasses \#5 through \#8 fromTable II were fabricated and visually examined for metallic copper. These glasses (of which \#5 through \#7 were targeted to contain $0.75 \mathrm{wt} \%$ total copper) closely resembled Glasses \#1 through \#4; that is, Glasses \#5 and \#6, which were targeted at REDOX ratios of 0.333 and 0.2 , respectively, were again brown with black swirls. The other two

2 In the remaining tests, the experimenter would add the approximate target amount of melter feed material to a pre-weighed alumina crucible. The mass of melter feed would be measured and used to recompute the amounts of copper nitrate, sucrose, and nitric acid necessary to obtain the target total copper concentration in glass and REDOX ratio. An example of this computation is provided in Appendix B. 
glasses, \#7 and \#8, were black and shiny as expected. Thus the decrease in targeted total copper concentration from 1.0 to $0.75 \mathrm{wt} \%$ did not significantly change the visual appearance of the glasses made. However, it was again apparent that not enough glass was being produced for the necessary durability and REDOX testing as a significant quantity of glass was unrecoverable just by breaking apart the crucibles.

Table II. Revised Run Plan for $>40 \mathrm{~g}$ of Melter Feed (or approx. $30 \mathrm{ml}$ batch) ${ }^{\dagger}$

(Assuming a 40g initial charge of melter feed, $\rho=1.314, \omega=47.09 \%, c \approx 40 \%$.)

\begin{tabular}{|c|c|c|c|c|c|c|}
\hline \# & $\begin{array}{c}\text { Target } \\
\mathrm{Fe}^{2+} / \Sigma \mathrm{Fe}\end{array}$ & $\begin{array}{c}\text { Target } \\
\mathrm{wt} \% \mathrm{Cu}\end{array}$ & $\begin{array}{c}\mathrm{Cu}\left(\mathrm{NO}_{3}\right)_{2} \\
\text { grams }\end{array}$ & $\begin{array}{c}\text { Sucrose } \\
\text { grams }\end{array}$ & $\begin{array}{c}50 \% \mathrm{HNO}_{3} \\
\text { grams }\end{array}$ & $\begin{array}{c}\begin{array}{c}\text { Final } \\
\text { wt\% Fe }\end{array} \\
\end{array}$ \\
\hline $4,8,16$ & 0.207 & 0.0 & - & -- & $\bar{~}$ & 6.95 \\
\hline 1 & 0.333 & \multirow{3}{*}{1.0} & \multirow{3}{*}{0.616} & 0.444 & -- & \multirow{3}{*}{6.863} \\
\hline 2 & 0.2 & & & 0.2 & -- & \\
\hline 3 & 0.091 & & & $\ldots$ & -- & \\
\hline 5 & 0.333 & \multirow{3}{*}{0.75} & & 0.39 & -- & \multirow{3}{*}{6.885} \\
\hline 6 & 0.2 & & 0.461 & 0.146 & -- & \\
\hline 7 & 0.091 & & & -- & 0.157 & \\
\hline 9,10 & 0.333 & 1.0 & 0.616 & 0.444 & -- & 6.863 \\
\hline 11,12 & 0.091 & 1.0 & 0.616 & -- & -- & 6.863 \\
\hline 13 & 0.333 & \multirow{3}{*}{0.5} & \multirow{3}{*}{0.306} & 0.336 & -- & \multirow{3}{*}{6.906} \\
\hline 14 & 0.2 & & & 0.093 & -- & \\
\hline 15 & 0.091 & & & -- & 0.32 & \\
\hline 17 & 0.333 & 1.25 & 0.773 & 0.499 & -- & 6.841 \\
\hline 18 & 0.5 & 1.25 & 0.773 & 0.81 & -. & 6.841 \\
\hline 19 & 0.333 & 1.0 & 0.616 & 0.444 & -- & 6.863 \\
\hline 20 & 0.5 & 1.0 & 0.616 & 0.754 & -- & 6.863 \\
\hline
\end{tabular}

† See Table I for additional information concerning the assumptions made to compute the values in this table.

Thus the next set of four crucibles (i.e., \#9 through \#12 from Table II) were filled with approximately 45 grams of melter feed as this appeared to correspond to the maximum volume of melter feed that would leave sufficient freeboard in the crucible during vitrification. The necessary copper nitrate, sucrose, and nitric acid were increased accordingly. Note that these four glasses (i.e., \#9 through \#12) in Table II are targeted differently than those shown in Table I. Due to time and resource constraints, it was decided to fabricate the glasses necessary for durability testing next. Since the glasses targeted at 0.75 and $1.0 \mathrm{wt} \%$ total copper acted similarly, the glasses that would be used to determine whether there was a significant impact of metallic copper on durability were fabricated to be $1 \mathrm{wt} \%$ total $\mathrm{Cu}$ in glass as shown in Table II. Furthermore, to assure that there was sufficient glass available for testing, duplicate crucibles were prepared at either end of the acceptable DWPF REDOX range (i.e., $\mathrm{Fe}^{2+} / \Sigma \mathrm{Fe}$ from 0.091 to 0.333 ). This would provide the maximum change in REDOX over which to find any potential effect on the PCT response.

The glasses were fabricated and then broken away from their respective crucibles. Again visual examination of these glasses agreed with expectations as the two glasses (\#11 and \#12) targeted at the oxidized end of the acceptable range were black and shiny like shown in Figure 5. The two glasses targeted at the reduced end of the acceptable range were either completely brown for Glass \#9 (See Figure 6) or brown with black swirls (for \#10). For the REDOX ratio and durability tests, only three glasses were chosen due to resource and timing constraints. Both reduced glasses were chosen since there already exists considerable information concerning PCT responses for oxidized glasses; Glass \#11 was selected (as the oxidized glass for comparison) since it had the most recoverable glass. Approximately 2 grams were collected from glasses \#9, 10, and 11 and sent to the Mobile Laboratory for REDOX ratio measurement. The approximately 12 grams of glass remaining from each of these three trials were sent to R. J. Workman of SRTC for PCT preparation and testing. The resulting PCT leachates were measured in duplicate by the SRTC Mobile Laboratory as part of an existing designed study [14]; this significantly reduced costs. 


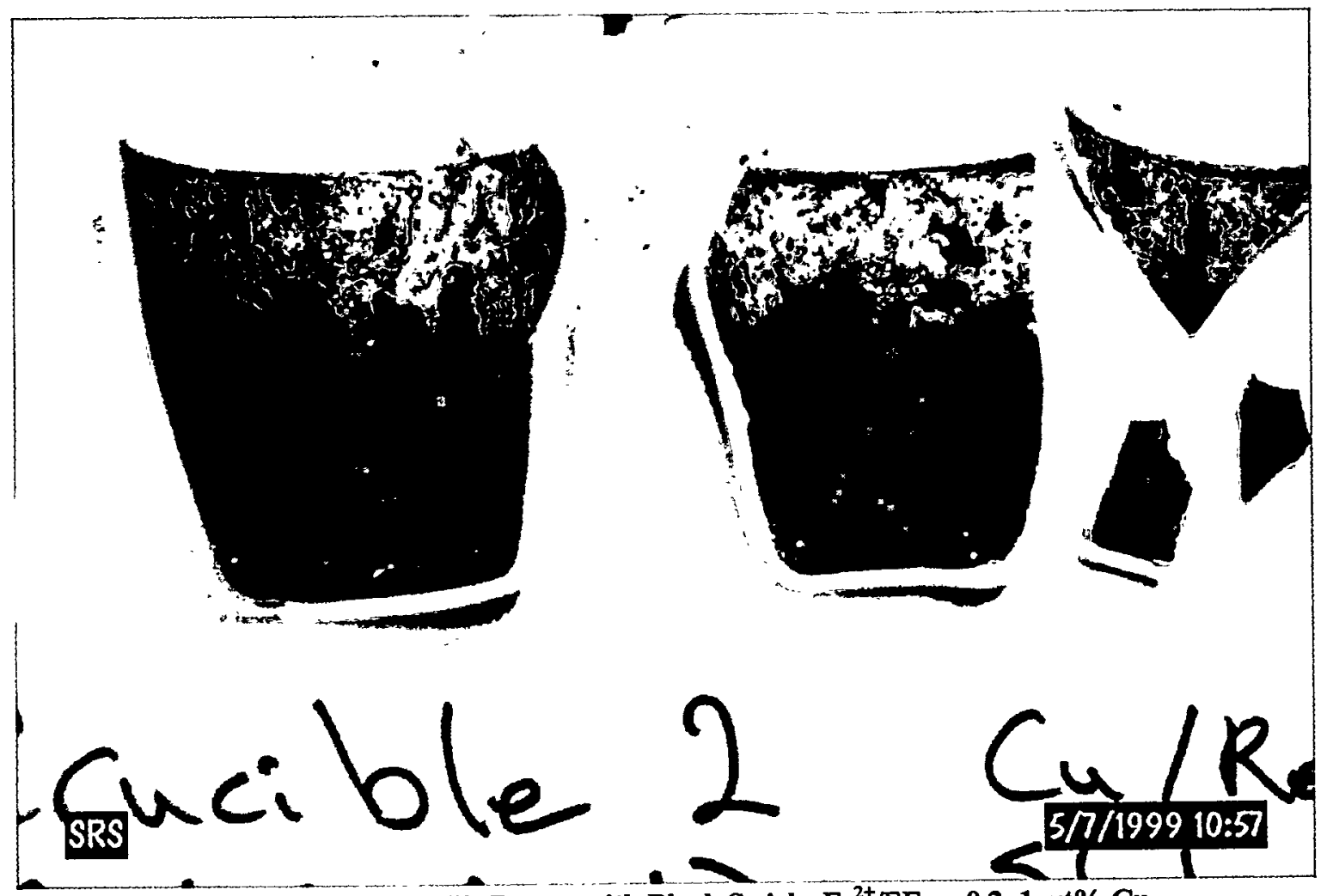

Figure 1. Glass \#2, Brown with Black Swirls, $\mathrm{Fe}^{2+} / \Sigma \mathrm{Fe}=0.2,1$ wt $\% \mathrm{Cu}$

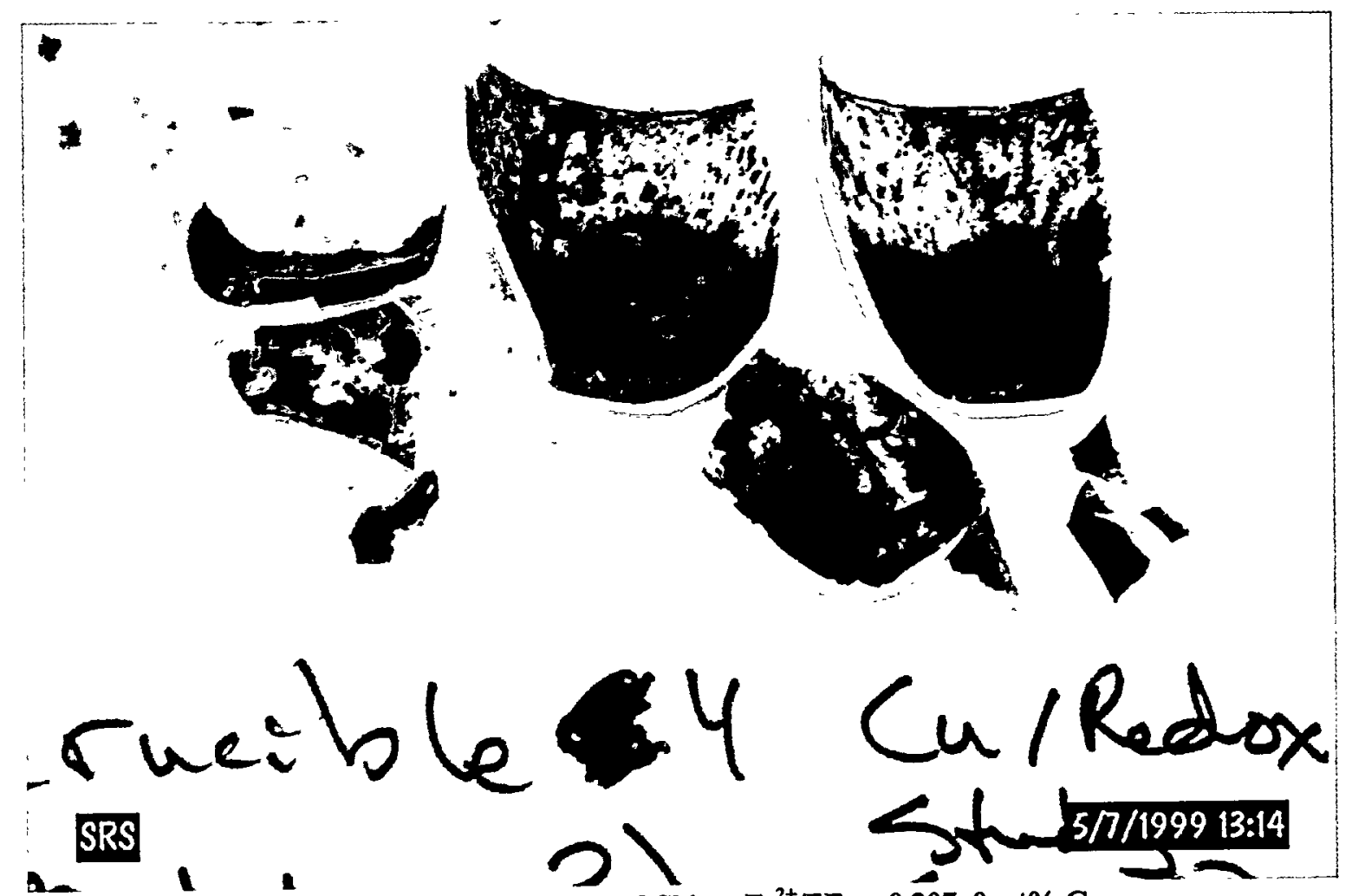

Figure 2. Glass \#4, Black and Shiny, $\mathrm{Fe}^{2+} / \Sigma \mathrm{Fe}=0.207,0 \mathrm{wt} \% \mathrm{Cu}$ 
WRSC-TR-99-00222, Rev. 0

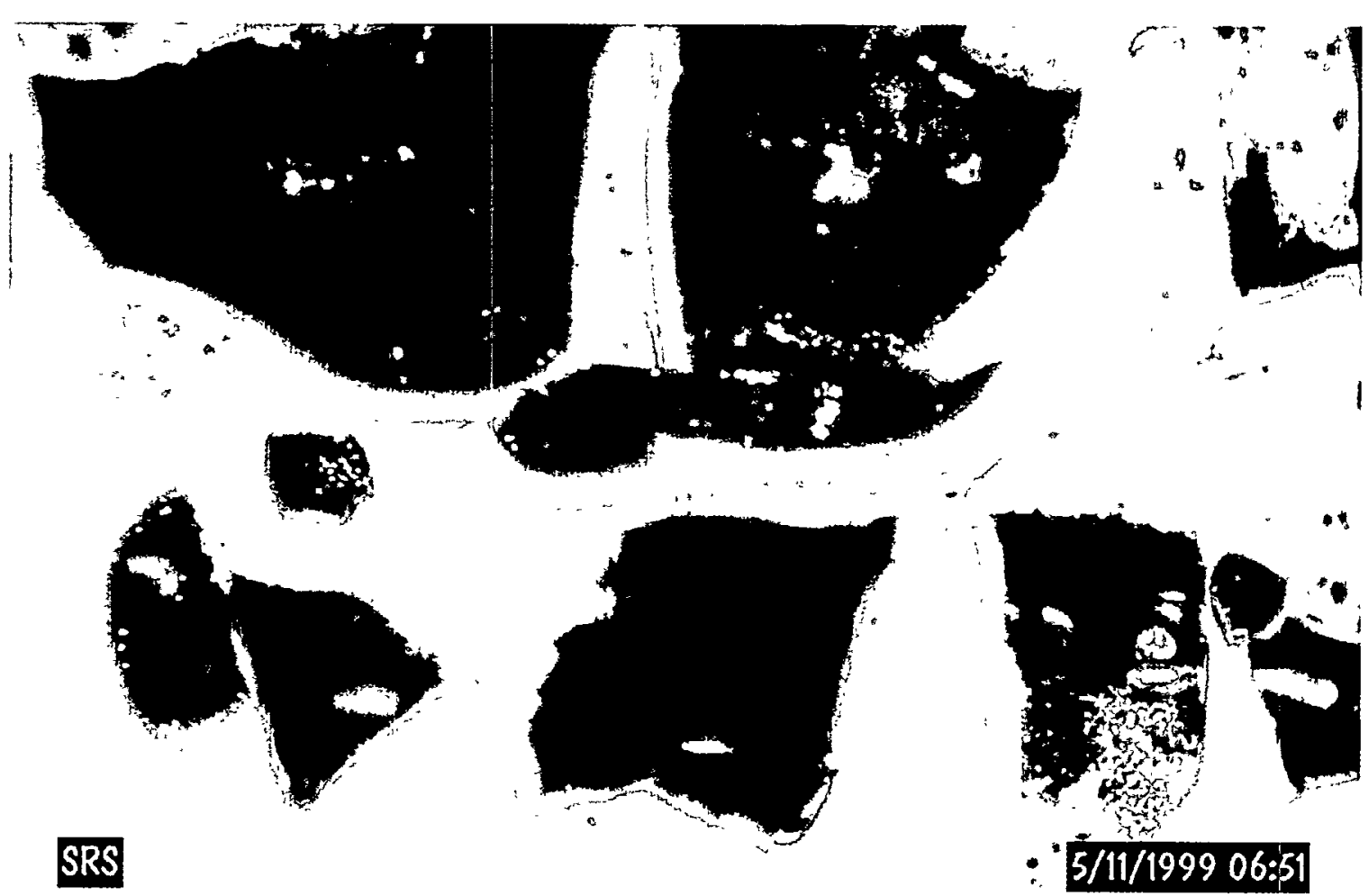

Figure 3. Glass \#6, Brown with Black Swirls, $\mathrm{Fe}^{2+} / \Sigma \mathrm{Fe}=0.2,0.75 \mathrm{wt} \% \mathrm{Cu}$
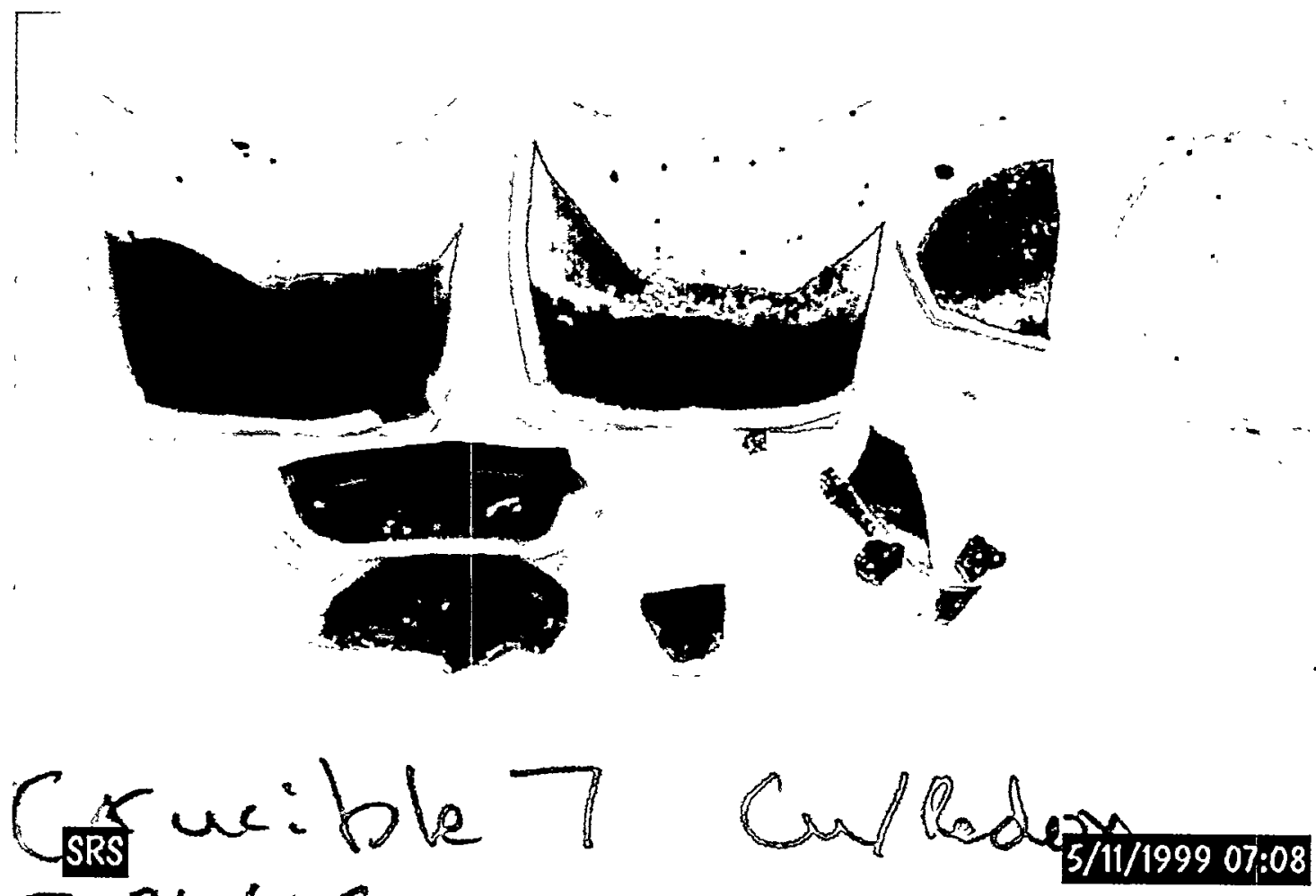

Figure 4. Glass \#7, Black and Shiny, $\mathrm{Fe}^{2+} / \Sigma \mathrm{Fe}=0.091,0.75 \mathrm{wt} \% \mathrm{Cu}$ 
The results of the REDOX and PCT measurements for Glasses \#9, 10, and 11 (including relevant glass standard information) are provided in Table III. It appears from these results that either the sucrose was a more effective reductant than originally thought, the formate concentration was underestimated, or both. However, the fact that measured REDOX ratios are outside the DWPF acceptable range should not matter for this particular study as only the effect of metallic copper on PCT response is under consideration. The acceptable range is bounded by the data in Table I, and metallic copper is only visually evident in the more reduced glasses. This should allow any effect of metallic copper to be investigated.

The measured PCT releases are also provided in Table III for $\mathrm{B}, \mathrm{Li}, \mathrm{Na}$, and Si. These results indicate that there was no significant impact of metallic copper $(1 \mathrm{wt} \%)$ on PCT response for these glasses, i.e. all glasses had acceptable PCT responses based upon EA glass. This is despite the fact that the more reduced glasses (i.e., \#9 and 10) in this table, which were targeted at the same elemental composition, should have been, in theory [15], less durable than the more oxidized glass (i.e., \#11). From these results, there appears to be no apparent danger from brown glass in terms of its effect on glass durability based upon the PCT. However, more tests will be necessary to make this assertion definitive.

Table III. REDOX and PCT Measurements for Glasses \#9, 10, and 11

\begin{tabular}{cccccc}
\hline & & \multicolumn{5}{c}{ PCT Release, $\mathrm{ppm}^{\mathrm{ff}}$} \\
Glass ID & $\mathrm{Fe}^{2+} / \Sigma \mathrm{Fe}^{\dagger}$ & $\mathrm{B}$ & $\mathrm{Si}$ & $\mathrm{Na}$ & $\mathrm{Li}$ \\
\hline 9 & 0.508 & 14.18 & 77.17 & 47 & 10.37 \\
& 0.504 & 14.92 & 75.5 & 44 & 9.05 \\
\hline 10 & 0.534 & 13.65 & 76 & 46.66 & 10.12 \\
& 0.538 & 15.5 & 73.83 & 44.33 & 8.95 \\
\hline 11 & 0.047 & 14.7 & 81.33 & 41.5 & 9.67 \\
& 0.052 & 14.32 & 84.5 & 42.83 & 9.18 \\
\hline
\end{tabular}

$\uparrow$ The EA glass standard measurements were 0.193 and 0.191 versus an accepted value of 0.18 .

tt The average ARM glass standard measurements for $\mathrm{B}, \mathrm{Si}, \mathrm{Na}$, and $\mathrm{Li}$ were $18.8,60.5,38.6$, and $14.6 \mathrm{ppm}$, respectively versus accepted values [15] of $17.6,60.9,36.9$, and $13.7 \mathrm{ppm}$, respectively.

Another set of experiments were executed while waiting for the measured values represented in Table III. Glasses \#13 through \#16 from Table II were fabricated to see if decreasing the target total copper concentration to $0.5 \mathrm{wt} \%$ in glass - the current DWPF limit [7]-would profoundly change the appearance of the glasses produced. The glasses were broken away from their respective crucibles and examined visually. Glasses \#13 and 14 were brown with black swirls and half brown/half black, respectively. An image of Glass \#13 is shown in Figure 7. From the results presented in Table III, these glasses may have been significantly more reduced than targeted which may have accounted for the copious amounts of metallic copper present. Glasses \#15 and 16 were both black and shiny, as expected. An image of Glass \#15 is shown inFigure 8. Thus for a constant targeted REDOX ratio, there does appear to be a general diminishment in the amount of visible metallic copper present in the glasses as the total targeted copper concentration decreases. However, there can be significant metallic copper present in these glasses even when the targeted copper concentration is at the current DWPF limit of $0.5 \mathrm{wt} \%$ in glass. The data in Table III suggests that there is not likely any deleterious effect of this metallic copper on the PCT response. 
WR'SC-TR-99-00222, Rev. 0

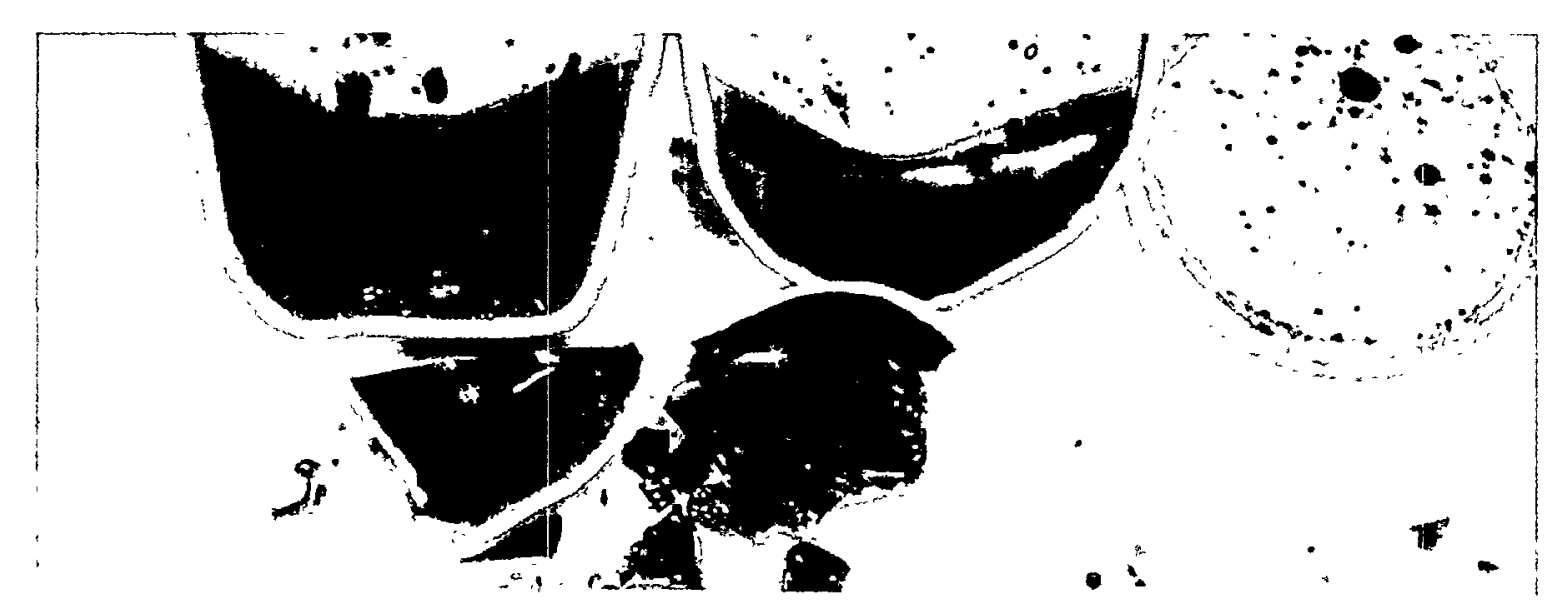

irucible ll CalRodox Br

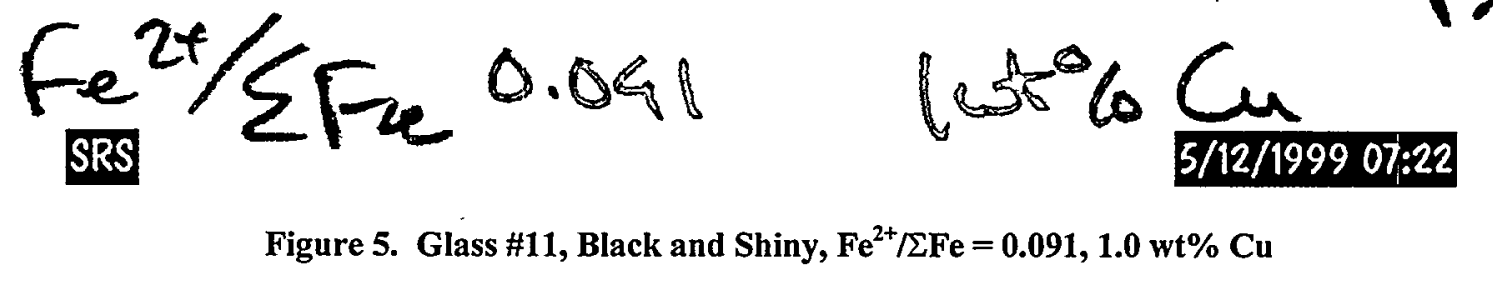

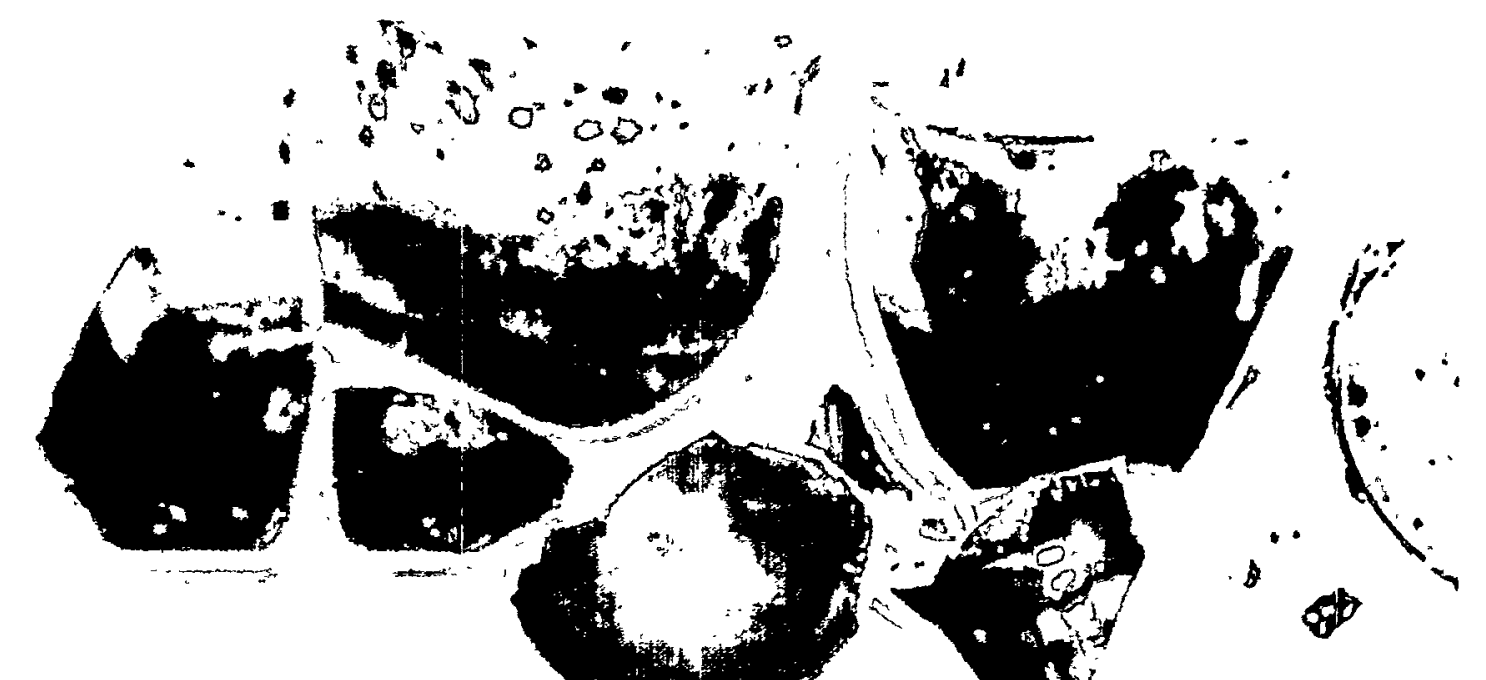

Cruribleq Culkedok or

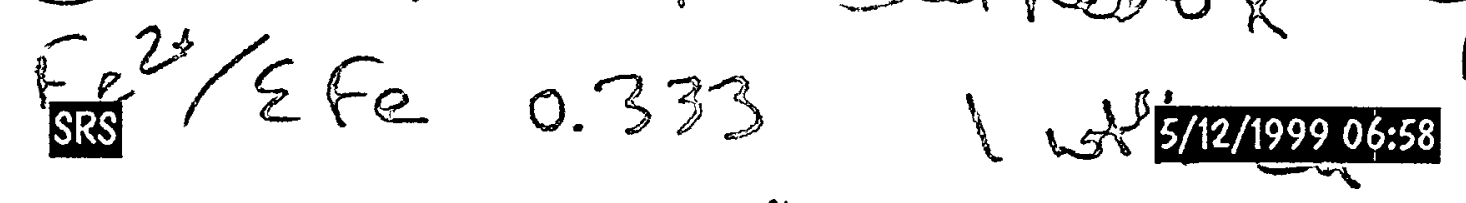
Figure 6. Glass \#9, Brown, $\mathrm{Fe}^{2+} / \Sigma \mathrm{Fe}=0.333,1.0 \mathrm{wt} \% \mathrm{Cu}$ 


\section{Metallic Copper Settling in the Crucible Studies}

Thus there appears to be no profound deleterious effect of metallic copper on the PCT response; however, this was not the only potential problem stemming from metallic copper at visible levels. If metallic copper forms in the melt, there is some chance that a sufficient quantity of it may settle to the melter floor to create a conductive path and resulting electrical short. Thus any indication that the copper is settling-even in a crucible-would be important information for DWPF process control.

For the glasses produced from the first 16 trials, there was no indication that metallic copper was settling to the crucible floor. On the contrary, there was normally a darker, occasionally black, region of glass around the crucible bottom, sides, and melt line. This was considered to be likely a reaction between the glass and either the alumina crucible or air that resulted in a small layer of more oxidized glass. For the glasses that contained both brown (i.e., visible metallic copper) and black glass, the brown glass did not seem to be any more likely to be closer to the bottom of the crucible than the top. The metallic copper thus appeared to remain suspended in the glass; no tendency to settle was observed for the 16 glasses melted for an hour based upon the vitrification for REDOX measurement procedure.

However, the results for the original 16 glasses beg a question as to whether the copper would settle given more time to do so. To provide information concerning this potential phenomenon, a set of four additional glasses, \#17 through 20, were fabricated using a much longer melt time of over eight hours. Furthermore, since there was insufficient funding to measure compositions for the glasses, two of the glasses (i.e., \#17 and 18) were targeted for a total copper concentration of $1.25 \mathrm{wt} \%$ in glass to assure that glasses with total copper concentrations greater than $1 \mathrm{wt} \%$ in glass would be considered. Glasses \#19 and 20 were again targeted at a total copper concentration of $1 \mathrm{wt} \%$ in glass. Also since the REDOX ratio measurements were not available at the time of the experiment, sufficient sucrose was added to two of the glasses (i.e., \#18 and 20) to attain targeted REDOX ratios of $\mathrm{Fe}^{2+} / \Sigma \mathrm{Fe}=0.5$. The final two glasses (i.e., \#17 and 19) in this study were targeted to have $\mathrm{REDOX}$ ratios of $\mathrm{Fe}^{2+} / \Sigma \mathrm{Fe}=0.333$.

Glasses \#17 through 20 were melted at $1150^{\circ} \mathrm{C}$ for over eight hours. After cooling the glasses were broken away from their respective crucibles and examined. All four glasses were primarily brown throughout the middle layer. Glasses \#17, 19 and 20 exhibited a darker layer around the crucible and melt interfaces. Glass \#18 was consistently brown throughout including the interfaces. For the two glasses (i.e., \#17 and 19) targeted at a REDOX ratio of $\mathrm{Fe}^{2+} / \mathrm{Fe}=0.333$ (which may have had significantly higher REDOX ratios as indicated in Table III), there again was no evidence of metallic copper settling. However, the two glasses (i.e., \#18 and 20) that were targeted at very reduced conditions of $\mathrm{Fe}^{2+} / \Sigma \mathrm{Fe}=0.5$ (and which were likely even more reduced), possessed small, round metallic nodules in at the glass-crucible bottom interface. Please seeFigure 9 and Figure 10 for images of Glass 18 and Glass 20 , respectively, where nodules are identified. Similar results have been observed by other researchers. These nodules were likely comprised of either metallic nickel, metallic copper, and nickel or copper sulfide. It is recommended that these nodules be examined to identify the major constituents. However, despite the appearance of the (likely) metallic nodules, this would not appear to present new concerns for DWPF processing as the glasses were much more reduced than allowed in DWPF. There was no evidence of metallic deposition in the glasses studied until conditions were unreasonably reduced: conditions where the deposition of metallic nickel has already been observed? 3 Thus, based upon the information obtained in this study, there is no reason to expect any novel deposition concerns associated with the higher copper concentrations studied at allowable REDOX conditions.

3 According to Schreiber [3], the fractions of metallic nickel and copper at the conditions where deposition was discovered were approximately an order of magnitude higher than those expected for the most reduced conditions currently allowed for DWPF processing. 
rucible 13 culkedor Ger ${ }^{2+} / \mathrm{EFe} 0.333$ o.5 wor ch

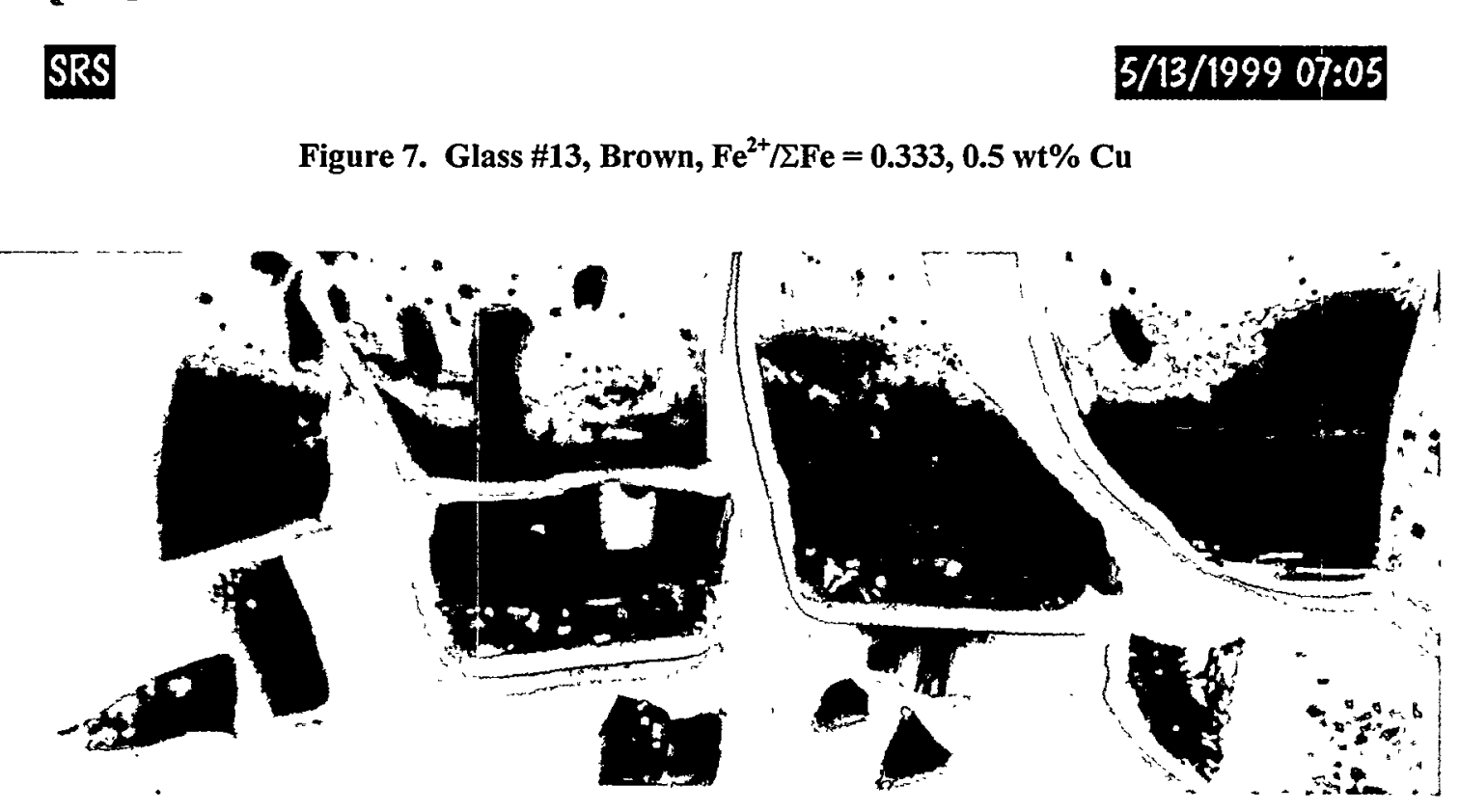

Srucible 15 culRedox

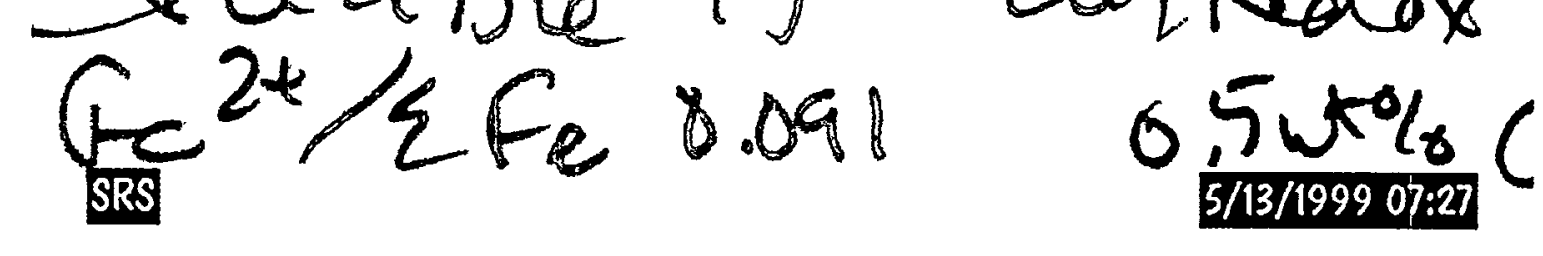




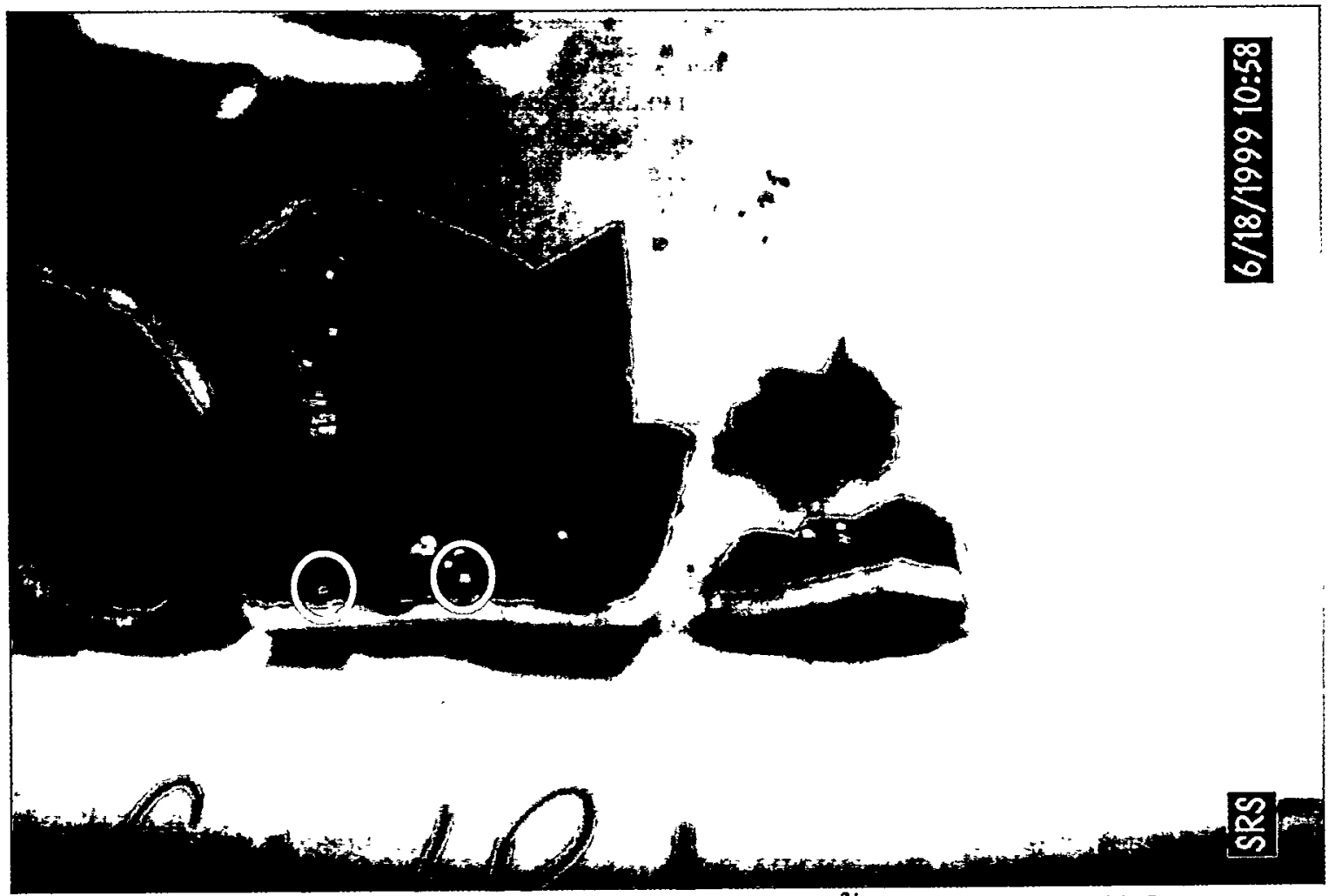

Figure 9. Glass \#18, Brown, Nodules Circled, $\mathrm{Fe}^{2+} / \Sigma \mathrm{Fe}=0.5,1.25 \mathrm{wt} \% \mathrm{Cu}$

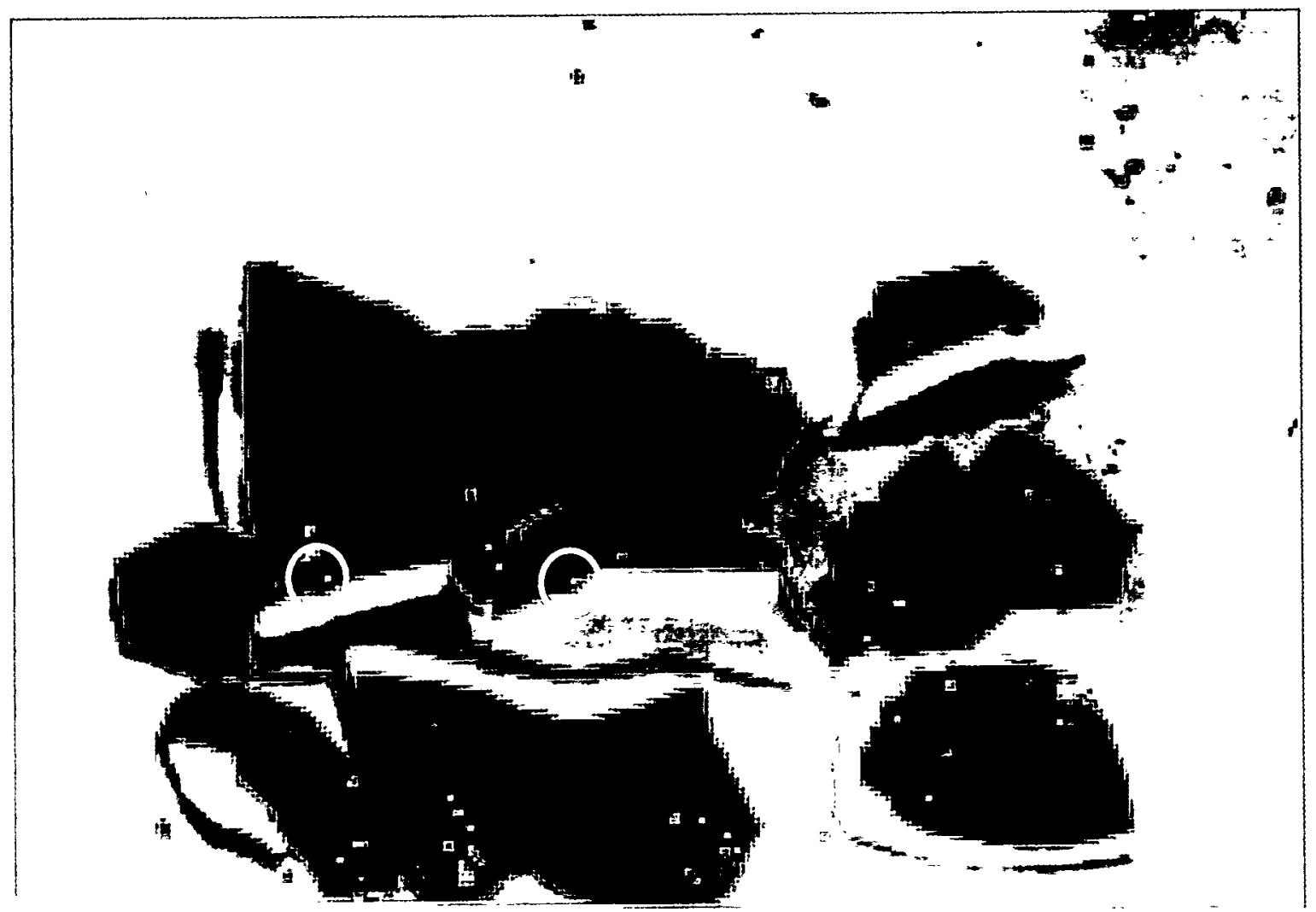

Figure 10. Glass \#20, Black Interface, Brown Middle, Nodules Circled, $\mathrm{Fe}^{2+} / \Sigma \mathrm{Fe}=0.5,1.0 \mathrm{wt} \% \mathrm{Cu}$ 


\section{Targeted Versus Measured Values}

Table IV summarizes the experiments, measurements, and visual results for the twenty glasses fabricated for the copper study. Most of the added masses represented in this table were very close to those targeted in the designs provided in Table I and Table II. The only mass that is somewhat distant from the corresponding targeted value is that of the sucrose added to Glass \#20. This occurred because a target value of 0.757 grams was translated into a value of 0.575 grams prior to the addition. However, this mass of sucrose still translated into a target REDOX ratio greater than 0.40 (and likely higher in the actual glass based upon the results in Table III); therefore, the REDOX ratio of Glass \#20 was most likely considerably above the upper limit of 0.33 for DWPF processing.

The only other minor discrepancies in the data involved the final total copper concentrations in the glasses produced when the measured mass of glass was used to compute the concentration. Most of these differences were significantly less than $7 \%$ of the original target value. This difference is well within the $95 \%$ confidence limits [7] that would be associated with measurements of the total copper concentration. Thus these differences do not appear significant enough to cast doubts on the conclusions drawn in this memorandum. For example, it is unlikely that a small increase in the total copper concentration in Glasses \#9 through 11 would result in vastly different PCT responses and, thus, change the conclusion that the metallic copper appears to have no profound, deleterious impact on the PCT response. Finally, the results for Glass \#17, which certainly contained more than $1 \mathrm{wt} \%$ copper, reinforces the fact that settling was not observed in these studies for any reasonable REDOX conditions for DWPF.

\section{A PHA LIMIT FOR PROCESSING}

Thus, based upon these results, it appears that as much as $1 \mathrm{wt} \%$ total copper may be tolerated in DWPF glass. Since copper primarily comes from the PHA stream (where it is added as a catalyst), this maximum limit in glass can be translated into a limit on the amount that can be added to the PHA. From the PHA/Glass testing studies currently being performed by SRTC, the maximum fraction, p, of PHA oxides (not including the MST) expected in glass is 0.13 [16]. Since it can be assumed that all copper will come from the PHA stream, then the maximum total copper concentration in glass, $c_{\mathrm{g}}$, can first be translated into an analogous constraint on the maximum total copper concentration that can be tolerated in the PHA, $c_{p}$, on an oxide basis:

$$
\begin{aligned}
& c_{g} \leq 1.0 \text { grams } \mathrm{Cu} / 100 \text { grams glass } \\
& c_{g}=p c_{p} \text { where } p=0.13 \text { or } c_{p} \leq\left(\frac{c_{g}}{p}=\frac{1.0}{0.13}=7.69\right) \text { grams } \mathrm{Cu} / 100 \text { grams PHA oxides. }
\end{aligned}
$$

Normally, the computed PHA oxides (since PHA material cannot be calcined) per gram of measured PHA total solids is approximately 0.40 . Denote the parameter describing this ratio as $f_{\mathrm{p}}$. Thus this limit on a total solids basis, $\mathrm{s}_{\mathrm{p}}$, is:

$$
\mathrm{s}_{\mathrm{p}} \leq\left(\frac{\mathrm{c}_{\mathrm{g}} f_{\mathrm{p}}}{\mathrm{p}}=\frac{(1.0)(0.40)}{0.13}=3.08\right) \text { grams Cu/100 grams PHA total solids. }
$$

Finally, since the PHA composition is measured based upon a total slurry basis (i.e., ppm), the measured total solids, $\omega_{\mathrm{p}}$ grams total solids per gram of slurry, for the stream can be used to translate the copper limit into one, $\mathrm{p}_{\mathrm{p}}$, on the same basis as the PHA composition measurements. Using a nominal value of $\omega_{\mathrm{p}}=0.06$ provides the following limit on total copper in the PHA stream:

$$
\mathrm{p}_{\mathrm{p}} \leq\left(\frac{\mathrm{c}_{\mathrm{g}} f_{\mathrm{p}} \omega_{\mathrm{p}}}{\mathrm{p}}=\frac{(1.0)(0.40)(0.06)}{0.13} \times 10^{4}=1846\right) \mathrm{ppm} \text { total copper in PHA stream. }
$$

This limit will need to be recomputed whenever the PHA material changes. The pertinent error information should be used to assure that the copper concentration in the PHA is low enough as to not violate the glass limit. 


\section{WSRC-TR-99-00222, Rev. 0}

Table IV. Summary of Crucible Runs for Salt Disposition Copper Studies

\begin{tabular}{|c|c|c|c|c|c|c|c|c|c|c|c|c|}
\hline \multirow[b]{2}{*}{$\#$} & \multicolumn{2}{|c|}{ Original Targets } & \multirow{2}{*}{$\begin{array}{l}\text { Batch } \\
\text { grams }\end{array}$} & \multirow{2}{*}{$\begin{array}{c}\mathrm{Cu}\left(\mathrm{NO}_{3}\right)_{2} \\
\text { grams }\end{array}$} & \multirow{2}{*}{$\begin{array}{c}\text { Sucrose } \\
\text { grams }\end{array}$} & \multirow{2}{*}{$\begin{array}{c}50 \% \mathrm{HNO}_{3} \\
\text { grams }\end{array}$} & \multicolumn{3}{|c|}{ Revised Targets } & \multicolumn{2}{|c|}{ Glass } & \multirow[b]{2}{*}{ Visual $^{t}$} \\
\hline & $\mathrm{Fe}^{2+} / \Sigma \mathrm{Fe}$ & $\mathrm{wt} \% \mathrm{Cu}$ & & & & & $\mathrm{Fe}^{2+} / \Sigma \mathrm{Fe}$ & $\mathrm{wt} \% \mathrm{Cu}$ & Glass (g) & grams & $\mathrm{wt} \% \mathrm{Cu}$ & \\
\hline 1 & 0.333 & 1.0 & 30.0008 & 0.4600 & 0.3334 & 0 & 0.334 & 0.996 & 12.7123 & 12.1518 & 0.952 & b-§k \\
\hline 2 & 0.2 & 1.0 & 30.0001 & 0.4596 & 0.1506 & 0 & 0.201 & 0.995 & 12.7248 & 12.1514 & 0.95 & b- $\$ k$ \\
\hline 3 & 0.091 & 1.0 & 29.9988 & 0.4613 & 0 & 0 & 0.09 & 0.998 & 12.9017 & 12.1514 & 0.94 & $\mathrm{k} \& \mathrm{~s}$ \\
\hline 4 & 0.207 & 0.0 & 30.0036 & 0 & 0 & 0 & 0.207 & 0.0 & 12.6679 & 12.0014 & 0 & k\&s \\
\hline 5 & 0.333 & 0.75 & 40.1131 & 0.4592 & 0.3919 & 0 & 0.334 & 0.746 & 17.2189 & 16.1964 & 0.701 & $\mathrm{~b}-\S \mathrm{k}$ \\
\hline 6 & 0.2 & 0.75 & 40.4322 & 0.4657 & 0.1609 & 0 & 0.207 & 0.75 & 17.2963 & 16.3262 & 0.708 & $b-\$ k$ \\
\hline 7 & 0.091 & 0.75 & 40.3175 & 0.4635 & 0 & $0.1893^{t \dagger}$ & 0.086 & 0.749 & 17.403 & 16.2796 & 0.7 & k\&s \\
\hline 8 & 0.207 & 0.0 & 40.1175 & 0 & 0 & 0 & 0.207 & 0.0 & 17.203 & 16.047 & 0 & k\&s \\
\hline 9 & 0.333 & 1.0 & 45.1815 & 0.6966 & 0.5014 & 0 & 0.333 & 1.001 & 19.4517 & 18.3019 & 0.942 & $\mathrm{~b}-/ \mathrm{k}$ \\
\hline 10 & 0.333 & 1.0 & 45.2876 & 0.6988 & 0.5026 & 0 & 0.333 & 1.002 & 19.3127 & 18.3451 & 0.952 & $b-\S k$ \\
\hline 11 & 0.091 & 1.0 & 45.7088 & 0.7035 & 0 & 0 & 0.09 & 0.999 & 19.7065 & 18.5151 & 0.939 & k\&s \\
\hline 12 & 0.091 & 1.0 & 45.7681 & 0.7067 & 0 & 0 & 0.09 & 1.002 & 19.7221 & 18.5399 & 0.942 & k\&s \\
\hline 13 & 0.333 & 0.5 & 40.2898 & 0.3072 & 0.3379 & 0 & 0.333 & 0.498 & 17.3013 & 16.2171 & 0.467 & b- §k \\
\hline 14 & 0.207 & 0.5 & 40.1809 & 0.3069 & 0.1064 & 0 & 0.207 & 0.499 & 17.2554 & 16.1734 & 0.468 & $1 / 2 b-1 / 2 k$ \\
\hline 15 & 0.091 & 0.5 & 40.3841 & 0.3099 & 0 & $0.3481^{\ddagger}$ & 0.087 & 0.501 & 17.383 & 16.2557 & 0.469 & k\&s \\
\hline 16 & 0.207 & 0.0 & 40.1678 & 0 & 0 & 0 & 0.207 & 0.0 & 17.3598 & 16.0671 & 0 & $\mathrm{k} \& \mathrm{~s}$ \\
\hline 17 & 0.333 & 1.25 & 40.1705 & 0.7779 & 0.5008 & 0 & 0.333 & 1.253 & 17.5257 & 16.3243 & 1.167 & b-ki \\
\hline 18 & 0.5 & 1.25 & 40.1409 & 0.7763 & 0.8133 & 0 & 0.5 & 1.252 & 17.3109 & 16.3119 & 1.179 & $\mathrm{~b}-/ \mathrm{k}, \mathrm{m}$ \\
\hline 19 & 0.333 & 1.0 & 40.1763 & 0.6194 & 0.4457 & 0 & 0.333 & 1.001 & 17.305 & 16.2744 & 0.941 & b-ki \\
\hline 20 & 0.5 & 1.0 & 40.1651 & 0.6181 & 0.5754 & 0 & 0.403 & 0.999 & 17.3203 & 16.2695 & 0.939 & b-ki,m \\
\hline
\end{tabular}

† The possible visual appearances are summarized as follows: brown (b), swirling ( $($ ), black (k), shiny (s), interfaces (i), metallic (m) nodules, and not or without $(I)$.

tt This addition was made with $10.2 \mathrm{M}$ nitric acid so the moles of $\mathrm{HNO}_{3}$ added were $1.486 \times 10^{-3}$.

$\ddagger$ This addition was made with $10.2 \mathrm{M}$ nitric acid so the moles of $\mathrm{HNO}_{3}$ added were $2.733 \times 10^{-3}$. 


\section{CONCLUSIONS AND RECOMMENDATIONS}

The purpose of this study was to determine, as functions of total copper loading and iron REDOX in glass, any obvious dependence of the PCT response of a borosilicate glass on the presence of visible metallic copper. Glasses were fabricated incorporating 0.5 to over $1.0 \mathrm{wt} \%$ total copper in glass at varying iron REDOX ratios. These glasses bound the acceptable DWPF range for iron REDOX.

Three of the resulting glasses were selected based upon visual appearance: one was black and shiny and the other two had copious, visible metallic copper present (brown glass). These three glasses were analyzed for iron REDOX and PCT responses for $\mathrm{B}, \mathrm{Li}, \mathrm{Na}$, and $\mathrm{Si}$. These data indicated that the presence of precipitated, metallic copper did not negatively impact durability for the glasses tests. Visual examinations of the glasses made in this study (which included those more reducing than expected in DWPF) indicated that metallic copper does not appear to collect on the crucible bottoms under reasonable REDOX conditions $\left(0.09 \leq \mathrm{Fe}^{2+} / \Sigma \mathrm{Fe} \leq\right.$ 0.33). These results provide some reassurance that metallic copper may not deleteriously impact DWPF melter life via deposition on the melter floor. However, it is recommended that, at least, a small-scale melter run be made to confirm these findings.

Most of the conclusions in this study are based upon targeted melter feed compositions and not measured compositions. Therefore, any gross batching errors could not be determined. It is, therefore, recommended that a subset of the twenty glasses fabricated be measured for chemical composition (especially copper concentrations). Others should be selected and measured for iron REDOX ratios and PCT responses. These results will help to make the conclusion drawn from this study much more definitive. 


\section{REFERENCES}

1. Lee, L. M. and Kilpatrick, L. L. "A Precipitation Process for Supernate Decontamination," USERDA Report DP-1639, E. I. du Pont de Nemours \& Co., Inc., Savannah River Laboratory, 1982.

2. Young, S.R., Morrison ,J., Adamson, S.L., Baich, M.A., Marek, J.C., and Jacobs, R.A. "Campaign Report: Precipitate Hydrolysis Experimental Facility, Runs 25-36," WSRC-RP-89-538, Rev. 0, February 2, 1990.

3. Schreiber, H. D. and Hockman, A. L. "Redox Chemistry in Candidate Glasses for Nuclear Waste Immobilization." Journal of the American Ceramic Society, Vol. 70, No. 8, 1987, pp. 591-594.

4. Ramsey, W. G. and Schumacher, R. F. "Effects of Formate and Nitrate Concentration on Waste Glass Redox at High Copper Concentration." WSRC-TR-92-484, October 23, 1992.

5. Ramsey, W. G., Askew, N. M., and Schumacher, R. F. "Prediction of Copper Precipitation in the DWPF Melter from the Melter Feed Formate and Nitrate Content," WSRC-TR-92-385, Rev. 0, November 30, 1994.

6. Jantzen, C. M. et al., "Refractory Corrosion in the Defense Waste Processing Facility (DWPF): Effects of Melter REDuction/OXidation (REDOX) Equilibria," Draft of WSRC-RP-96-625, March 30, 1998.

7. Brown, K.G. and Postles, R.L. "SME Acceptability Determination for DWPF Process Control," WSRCTR-95-0364, Rev. 3, February 21, 1996.

8. Jantzen, C. M. and Plodinec, M. J., "Composition and Redox Control of Waste Glasses: Recommendation for Process Control Limit," DPST-86-773, November 19, 1986.

9. Baumann, E. W. "Colorimetric Determination of Iron(II) and Iron(III) in Glass," Analyst, 117, 913-916 (1992).

10. Jantzen, C.M., Bibler, N.E., Beam, D.C., and Ramsey, W.G. "Nuclear Waste Glass Product Consistency Test (PCT)---Version 7.0," WSRC-TR-90-539, Rev. 7, $1995 .$.

11. Jantzen, C. M. "Vitrification of Melter Slurries for glass REDOX $\left(\mathrm{Fe}^{2+} / \Sigma \mathrm{Fe}\right)$ and Chemical Composition Measurement," Savannah River Laboratory Glass Technology Procedure Manual L13.1, Procedure GTOP3-046, Rev. 2, May 1998.

12. Controlled Laboratory Notebook WSRC-NB-99-00095.

13. Brown, K.G., Jantzen, C.M., and Pickett, J.B. "The Effects of Formate and Nitrate on REDuction/OXidation (REDOX) Process Control for the Defense Waste Processing Facility (DWPF)," WSRC-RP-97-34, Rev. 0, February 1997. (COMPANY PROPRIETARY)

14. Edwards, T.B. "An Analytical Plan for the SRTC Mobile Laboratory to Follow in Measuring PCT Solutions for Glass Tasks in the SDP," SRT-SCS-99-038, May 1999.

15. Jantzen, C.M, Pickett, J.B., Brown, K.G., Edwards, T.B., and Beam, D.C. "Process/Product Models for the Defense Waste Processing Facility (DWPF): Part I. Predicting Glass Durability from Composition Using a Thermodynamic Hydration Energy Reaction Model (THERMO)," WSRC-TR-93-672, Rev. 1, August 1, 1995.

16. Harbour, J.R. and Edwards, T.B. "DWPF Coupled Operation Chemistry-PHA Glass Testing," WSRCRP-99-00218, April 23, 1999. 
Appendix A

Computing $\mathrm{Cu}\left(\mathrm{NO}_{3}\right)_{2}$, Sucrose, and Nitric Acid Given Target Iron REDOX (i.e., $\mathrm{Fe}^{2+} / \Sigma \mathrm{Fe}$ ) and Total Copper Concentration in Glass 


$$
\mathrm{xf}_{\mathrm{Cu}}=100 \cdot \frac{\mathrm{c}^{\cdot} \cdot \mathrm{m}_{0} \cdot{ }^{\mathrm{x} 0} \mathrm{Cu}+\mathrm{m}_{1} \cdot \mathrm{mw}_{1}^{-1} \cdot \mathrm{mw}_{\mathrm{Cu}}}{\mathrm{c}_{\mathrm{m}} \cdot \mathrm{m}_{0}+\gamma \cdot \mathrm{m}_{1} \cdot \mathrm{mw}_{1}^{-1} \cdot \mathrm{mw}_{\mathrm{Cu}}} \quad \text { where } \quad \mathrm{mw}_{1}=\mathrm{mw}_{\mathrm{Cu}}+2 \cdot \mathrm{mw}_{\mathrm{NO} 3}+\alpha \cdot \mathrm{mw}_{\mathrm{H} 2}
$$

or

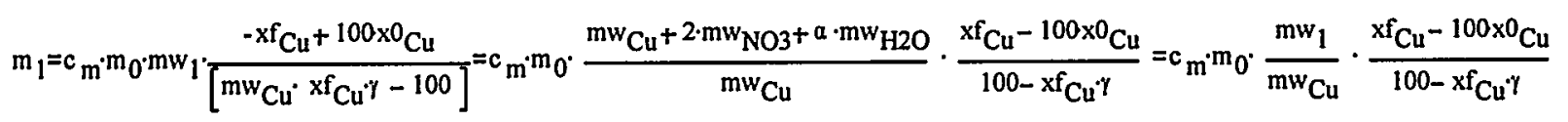

Now for the REDOX target:

$$
\mathrm{R}=\mathrm{A}+\left[\mathrm{B} \cdot\left[\frac{\mathrm{m}_{0}}{\rho_{\mathrm{m}}} \cdot \frac{\mathrm{x}^{0} \mathrm{COOH}}{\mathrm{mw} \mathrm{COOH}}+2 \cdot 12 \cdot \frac{\mathrm{m}_{3}}{\mathrm{mw}_{3}}\right]-\mathrm{C} \cdot\left[\frac{\mathrm{m}_{0}}{\rho_{\mathrm{m}}} \cdot \frac{\mathrm{x}^{0} \mathrm{NO}_{\mathrm{NO}}}{\mathrm{mw}_{\mathrm{NO} 3}}+2 \cdot \frac{\mathrm{m}_{1}}{\mathrm{mw}}+\mathrm{c}_{2} \cdot \frac{\mathrm{v}_{2}}{1000}\right]\right] \cdot \frac{1000}{\mathrm{~V}_{\mathrm{f}}} \cdot \frac{\omega_{\mathrm{t}}}{\omega_{\mathrm{f}}}
$$

Since we are making small additions to the melter feed, this can be approximated by:

$$
\mathrm{R}=\mathrm{A}+\left[\mathrm{B} \cdot\left[\frac{\mathrm{m}_{0}}{\rho_{\mathrm{m}}} \cdot \frac{\mathrm{x}^{0} \mathrm{COOH}}{\mathrm{mw}_{\mathrm{COOH}}}+2 \cdot 12 \cdot \frac{\mathrm{m}_{3}}{\mathrm{mw}_{3}}\right]-\mathrm{C} \cdot\left[\frac{\mathrm{m}_{0}}{\rho_{\mathrm{m}}} \cdot \frac{\mathrm{x}^{0} \mathrm{NO}_{3}}{\mathrm{mw}_{\mathrm{NO} 3}}+2 \cdot \frac{\mathrm{m}_{1}}{\mathrm{mw}_{1}}+\mathrm{c}_{2} \cdot \frac{\mathrm{v}_{2}}{1000}\right]\right] \cdot \frac{1000}{\mathrm{v}_{\mathrm{m}}} \cdot \frac{{ }^{\omega} \mathrm{t}}{{ }^{\omega} \mathrm{m}}
$$

where $V_{m}=\frac{m_{0}}{\rho_{m}} \quad$ or the exact solution(s) can be obtained upon substitution:

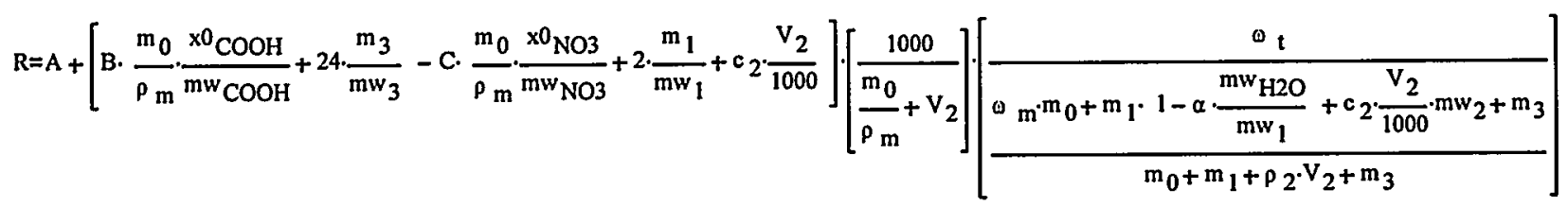

If looking for a more reduced feed, then $\mathrm{V}_{2}=0$ and:

(Approximate solution)

$\mathrm{m}_{3}=\frac{1}{24000} \cdot \mathrm{R}-\mathrm{A}-1000 \frac{{ }^{\omega} \mathrm{t}}{\omega_{\mathrm{m}}} \cdot \mathrm{B} \cdot \frac{{ }^{\mathrm{x}} \mathrm{COOH}}{\mathrm{mw} \mathrm{COOH}}+1000 \frac{{ }^{\omega} \mathrm{t}}{\omega_{\mathrm{m}}} \cdot \mathrm{C} \cdot \frac{{ }^{\mathrm{x} 0} \mathrm{NO} 3}{{ }^{\mathrm{mw}} \mathrm{NO}_{3}}+\frac{2000}{\mathrm{~m}_{0}} \cdot \rho_{\mathrm{m}} \cdot \frac{{ }^{\omega} \mathrm{t}}{\omega_{\mathrm{m}}} \cdot \mathrm{C} \cdot \frac{\mathrm{m}_{1}}{\mathrm{mw}_{1}} \cdot \frac{\mathrm{m}_{0}}{\rho_{\mathrm{m}} \cdot \omega_{\mathrm{t}}} \cdot \frac{{ }^{\omega} \mathrm{m}}{\mathrm{B}} \cdot \mathrm{mw}_{3}$

(Exact solutions where positive root is desired $\mathrm{m}_{3}$ )

If looking more a more oxidizing feed, then $\mathrm{m}_{3}=0$ and:

(Approximate solution)

$$
\mathrm{m}_{2}=\rho_{2} \cdot\left[-\mathrm{R}-\mathrm{A}-1000 \frac{{ }^{\omega} \mathrm{t}}{\omega^{\omega} \mathrm{m}} \cdot \mathrm{B} \cdot \frac{\mathrm{x}^{0} \mathrm{COOH}}{\mathrm{mw} \mathrm{COOH}}+1000 \cdot \frac{{ }^{\omega} \mathrm{t}}{{ }^{\omega} \mathrm{m}} \cdot \mathrm{C} \cdot \frac{{ }^{\mathrm{x}}{ }^{\mathrm{NO} 3}}{\mathrm{mw}_{\mathrm{NO} 3}}+\frac{2000}{\mathrm{~m}_{0}} \cdot \rho_{\mathrm{m}} \cdot \frac{\omega^{\omega} \mathrm{t}}{\omega_{\mathrm{m}}} \cdot \mathrm{C} \cdot \frac{\mathrm{m}_{1}}{\mathrm{mw}_{1}} \cdot \frac{\mathrm{m}_{0}}{\rho_{\mathrm{m}} \cdot{ }_{\mathrm{t}}} \cdot \frac{{ }^{\omega} \mathrm{m}}{\mathrm{C} \cdot \mathrm{c}_{2}}\right]
$$

(Exact solution where reasonable root is that desired)

$$
\text { or } \quad a_{2} \cdot v_{2}^{2}+b_{2} \cdot v_{2}+c_{2}=0
$$

where:

$$
a_{2}=\frac{1}{1000} \cdot(R-A) \cdot c_{2} \cdot m w_{2}+C \cdot c_{2} \cdot \omega t \cdot \rho_{2}
$$




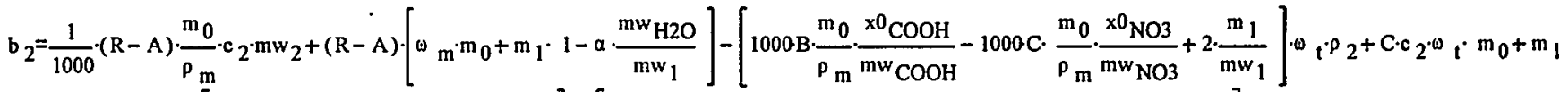

$$
\begin{aligned}
& c_{2}=(\mathrm{R}-\mathrm{A}) \cdot \frac{\mathrm{m}_{0}}{\rho_{\mathrm{m}}} \cdot\left[\omega_{\mathrm{m}} \cdot \mathrm{m}_{0}+\mathrm{m}_{1} \cdot 1-\alpha \cdot \frac{\mathrm{mw}_{\mathrm{H} 2 \mathrm{O}}}{\mathrm{mw}_{1}}\right]-\left[1000 \mathrm{~B} \cdot \frac{\mathrm{m}_{0}}{\rho_{\mathrm{m}}} \cdot \frac{\mathrm{x} 0_{\mathrm{COOH}}}{\mathrm{mw}_{\mathrm{COOH}}}-1000 \mathrm{C} \cdot \frac{\mathrm{m}_{0}}{\rho_{\mathrm{m}}} \cdot \frac{\mathrm{x} 0_{\mathrm{NO}}}{\mathrm{mw}_{\mathrm{NO}}}+2 \cdot \frac{\mathrm{m}_{1}}{\mathrm{mw}_{1}}\right] \cdot \omega_{\mathrm{t}} \cdot \mathrm{m}_{0}+\mathrm{m}_{1}
\end{aligned}
$$

For the following parameters:

$$
\begin{array}{lllll}
\mathrm{m}_{0}:=40.113 & { }^{\omega} \mathrm{m}:=\frac{47.0}{100} \quad c_{\mathrm{m}}:=0.4 \quad \rho_{\mathrm{m}}:=1.31 \quad \mathrm{~V}_{\mathrm{m}}:=\frac{\mathrm{m}_{0}}{\rho_{\mathrm{m}}} \quad \text { or } \quad \mathrm{V}_{\mathrm{m}}=30.527 \\
{ }^{\omega_{\mathrm{t}}}:=0.4 & \mathrm{x}_{\mathrm{Cu}}:=\frac{0}{100} \quad \mathrm{x}_{\mathrm{Fe}}:=\frac{6.95}{100} \quad{ }^{0}{ }_{\mathrm{COOH}}:=3120010^{-6} \quad \mathrm{x}_{\mathrm{NO} 3}:=1560010^{-6} \\
\mathrm{mw}_{\mathrm{Cu}}:=63.5 & \gamma:=1.251 \quad(\mathrm{Cu} \text { to } \mathrm{CuO}) \quad \mathrm{mw}_{\mathrm{H} 2 \mathrm{O}}:=2 \cdot 1.008+15.999 \quad \mathrm{mw}_{\mathrm{NO} 3}:=14.007+3 \cdot 15.999
\end{array}
$$

Addition 1: $\mathrm{Cu}\left(\mathrm{NO}_{3}\right)_{2} \cdot \mathrm{aH}_{2} \mathrm{O} \quad \alpha:=3 \quad \mathrm{mw}_{1}:=\mathrm{mw}_{\mathrm{Cu}}+2 \cdot \mathrm{mw}_{\mathrm{NO} 3}+\alpha \cdot \mathrm{mw}_{\mathrm{H} 2} \quad \mathrm{mw}_{1}=241.597$

Addition 2: $50 \%(10.35 \mathrm{M}) \mathrm{HNO}_{3} \mathrm{mw}_{2}:=1.008+\mathrm{mw}_{\mathrm{NO}} \rho_{2}:=1.304 \quad \mathrm{c}_{2}:=10.3$

Addition 3: Sucrose $\left(\mathrm{C}_{12} \mathrm{H}_{22} \mathrm{O}_{11}\right) \quad \mathrm{mw}_{3}:=12 \cdot 12.01115+22 \cdot 1.008+11 \cdot 15.999 \quad \mathrm{mw}_{3}=342.303$ $\mathrm{mw}_{\mathrm{COOH}}:=12.01115+2 \cdot 15.9994+1.00$

REDOX Coefficients: $\quad A:=0.21 \quad B:=0.25 \quad C:=0.73$

The necessary copper nitrate additions are:

$\mathrm{ml} \mathrm{xf}_{\mathrm{Cu}}:=\mathrm{c}_{\mathrm{m}} \cdot \mathrm{m}_{0} \cdot \frac{\mathrm{mw}_{1}}{\mathrm{mw}_{\mathrm{Cu}}} \cdot \frac{\mathrm{xf}_{\mathrm{Cu}}-100 \cdot \mathrm{x}^{0} \mathrm{Cu}}{100-\mathrm{xf}_{\mathrm{Cu}} \cdot \gamma} \quad \mathrm{xf}_{\mathrm{Cu}}:=\left[\begin{array}{c}1.0 \\ 0.75 \\ 0.5\end{array}\right] \quad \mathrm{i}:=0,1 .$. rows $\mathrm{xf}_{\mathrm{Cu}}-1$

$\mathrm{m}_{1_{\mathrm{i}}}:=\mathrm{ml} \mathrm{xf}_{\mathrm{Cu}_{\mathrm{i}}} \quad \mathrm{m}_{1}=\left[\begin{array}{l}0.618 \\ 0.462 \\ 0.307\end{array}\right] \quad \mathrm{xf}_{\mathrm{Fe}_{\mathrm{i}}}:=100 \frac{\mathrm{c}_{\mathrm{m}} \cdot \mathrm{m}_{0} \cdot \mathrm{x}_{\mathrm{Fe}}}{\mathrm{c}_{\mathrm{m}} \cdot \mathrm{m}_{0}+\gamma \cdot \mathrm{ml} \mathrm{xf}_{\mathrm{Cu}_{\mathrm{i}}} \cdot \frac{\mathrm{mw}_{\mathrm{Cu}}}{\mathrm{mw}_{1}}} \quad \mathrm{xf}_{\mathrm{Fe}}=\left[\begin{array}{l}6.863 \\ 6.885 \\ 6.906\end{array}\right]$

$\mathrm{m}_{1}:=\mathrm{m}_{1_{2}} \quad \mathrm{~m}_{1}=0.307$

Now let's look at the REDOX:

Case 1: For a more reducing feed, find the sucrose addition needed: $\quad R:=0.20$

$$
\mathrm{R}=0.207 \quad \mathrm{~m}_{1}=0.307
$$

One can first approximate using the fact that $V_{\mathrm{f}} \gg V_{m}\left(=m_{0} / r_{0}\right)$ and $\omega_{\mathrm{f}} \gg \omega_{\mathrm{m}}$ :

$$
\begin{aligned}
& \mathrm{m}_{\text {approx }}:=\frac{1}{24000} \cdot \mathrm{R}-\mathrm{A}-1000 \frac{{ }^{\omega} \mathrm{t}}{\omega_{\mathrm{m}}} \cdot \mathrm{B} \cdot \frac{\mathrm{x} 0_{\mathrm{COOH}}}{\mathrm{mw}_{\mathrm{COOH}}}+1000 \frac{{ }^{\omega} \mathrm{t}}{{ }^{\omega} \mathrm{m}} \cdot \mathrm{C} \cdot \frac{\mathrm{x} 0_{\mathrm{NO}}}{\mathrm{mw} w_{\mathrm{NO}}}+\frac{2000}{\mathrm{~m}_{0}} \cdot \rho_{\mathrm{m}} \cdot \frac{\omega^{\omega} \mathrm{t}}{\omega_{\mathrm{\omega}}} \cdot \mathrm{C} \cdot \frac{\mathrm{m}_{1}}{\mathrm{mw}_{1}} \cdot \frac{\mathrm{m}_{0}}{\rho_{\mathrm{m}}{ }^{\cdot \omega} \mathrm{t}} \cdot \frac{\omega^{\omega} \mathrm{m}}{\mathrm{B}} \cdot \mathrm{mw}_{3} \\
& \mathrm{~m} 3_{\text {approx }}=0.106
\end{aligned}
$$

$$
\mathrm{m}_{3}=\left[\begin{array}{c}
-40.44 \\
0.106
\end{array}\right] \quad \mathrm{m}_{1}=0.307
$$


Case 2: For a more oxidizing feed, find the nitric acid addition needed:

$$
\mathrm{R}:=\frac{0.1}{1+0.1} \quad \mathrm{R}=0.091
$$

One can again approximate using the fact that $V_{f} \gg V_{m}\left(=m_{0} / r_{0}\right)$ and $\omega_{f} 》 \omega_{m}$ :

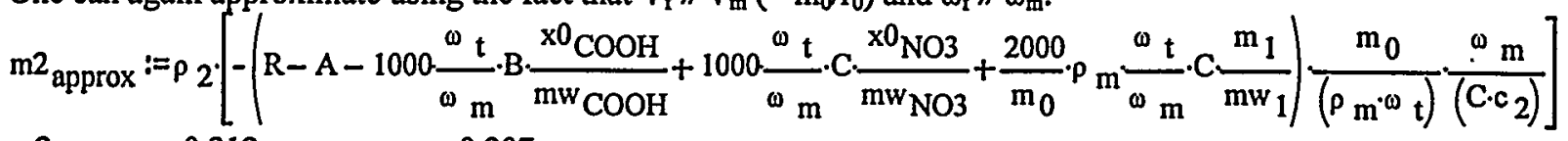

$$
\begin{aligned}
& \mathrm{m}^{2} \text { approx }=0.312 \quad . \mathrm{m}_{1}=0.307 \\
& a_{2}:=\frac{1}{1000} \cdot(R-A) \cdot c_{2} \cdot m w_{2}+C \cdot c_{2} \cdot \omega \cdot t^{\cdot}{ }_{2}
\end{aligned}
$$

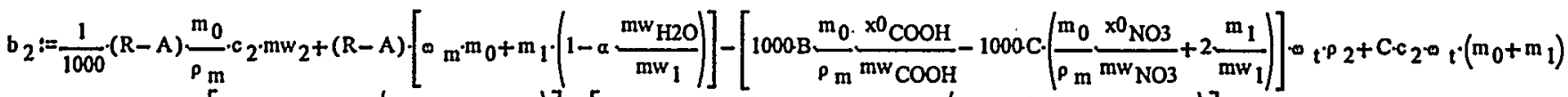

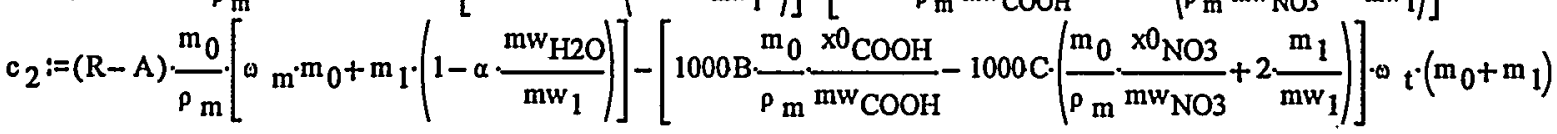

$$
\begin{aligned}
& \rho_{2} \cdot\left[\begin{array}{l}
\frac{1}{\left(2 \cdot a_{2}\right)} \cdot\left(-b_{2}+\sqrt{b_{2}^{2}-4 \cdot a_{2} \cdot c_{2}}\right) \\
\frac{1}{\left(2 \cdot a_{2}\right)} \cdot\left(-b_{2}-\sqrt{b_{2}^{2}-4 \cdot a_{2} \cdot c_{2}}\right)
\end{array}\right]=\left[\begin{array}{c}
0.32082 \\
-40.42066
\end{array}\right]
\end{aligned}
$$

Checked by: W. E. Daniel Date: $2-899$

19 


\section{Appendix B}

Computing Target Iron REDOX (i.e., $\mathrm{Fe}^{2+} / \mathrm{Fe}$ ) and Total Copper Concentration in Glass Given Masses of $\mathrm{Cu}\left(\mathrm{NO}_{3}\right)_{2}$, Sucrose, and Nitric Acid Added 


$$
\begin{aligned}
& m_{0}:=40.165 \mathrm{~km} \quad \text { This is the approximate batch mass in the crucible. } \\
& { }^{\circ} \mathrm{m}:=47.09 \frac{\mathrm{gm}}{100 \mathrm{gm}} \quad c_{\mathrm{m}}:=0.4 \quad \rho_{\mathrm{m}}:=1.314 \frac{\mathrm{gm}}{\mathrm{mL}} \quad \mathrm{V}_{\mathrm{m}}:=\frac{\mathrm{m}_{0}}{\rho_{\mathrm{m}}} \quad \text { or } \quad \mathrm{V}_{\mathrm{m}}=30.56 \gamma_{\mathrm{mL}} \quad \text { Volume of SME material needed } \\
& { }^{\mathrm{x}}{ }_{\mathrm{Cu}}:=0 \frac{\mathrm{gm}}{\mathrm{m}^{0} \mathrm{Cu}}:=\mathrm{c}_{\mathrm{m}} \cdot \mathrm{m}_{0} \cdot \mathrm{x}^{0} \mathrm{Cu} \quad \text { or } \quad{ }^{\mathrm{m} 0} \mathrm{Cu}_{\mathrm{u}}=0 \mathrm{gm} \quad \text { Initial mass of total } \mathrm{Cu} \\
& { }^{x} 0_{\mathrm{Fe}}:=6.95 \frac{\mathrm{gm}}{100 \mathrm{gm}} \quad{ }^{\mathrm{m} 0} \mathrm{Fe}:=\mathrm{c}_{\mathrm{m}} \cdot \mathrm{m}_{0} \cdot{ }^{0} \mathrm{Fe} \quad \text { or } \quad{ }^{\mathrm{m} 0} \mathrm{Fe}_{\mathrm{Fe}}=1.117 \mathrm{gm} \quad \text { Initial mass of total } \mathrm{Fe} \\
& { }^{x}{ }^{0} \mathrm{COOH}^{:=31200} \frac{10^{-6} \cdot \mathrm{gm}}{\mathrm{mL}} \quad \mathrm{M}^{0} \mathrm{COOH}:=\mathrm{V}_{\mathrm{m}} \frac{{ }^{\mathrm{x}} \mathrm{COOH}}{45.0183 \mathrm{gm} \cdot \mathrm{mor}^{1}} \quad{ }^{\mathrm{M} 0} \mathrm{COOH}^{=0.021 \mathrm{~mol}} \quad \text { Initial moles } \\
& { }^{x 0} \mathrm{NO}_{3}:=15600 \frac{10^{-6} \cdot \mathrm{gm}}{\mathrm{mL}} \quad \mathrm{MO}_{\mathrm{NO} 3}:=\mathrm{V}_{\mathrm{m}} \frac{{ }^{x} \mathrm{NO}}{62.0052 \mathrm{gm} \cdot \mathrm{mor}^{1}} \quad \mathrm{M}^{\mathrm{NO} 3}=7.69 \cdot 10^{-3} \mathrm{~mol} \quad \text { Initial moles } \\
& \text { REDOX } \omega, V, M C O O H, M N O 3):=\mid \begin{array}{l}
\mathrm{cCOOH}-0.001 \cdot \mathrm{MCOOH} \cdot \mathrm{V}^{-1} \\
\mathrm{cNO}+-0.001 \cdot \mathrm{MNO} \cdot \mathrm{V}^{1} \\
0.217+\left(0.253 \frac{\mathrm{m}^{3}}{\mathrm{~mol}} \cdot \mathrm{cCOOH}-0.739 \frac{\mathrm{m}^{3}}{\mathrm{~mol}} \cdot \mathrm{cNO} 3\right) \cdot\left(\frac{0.45}{\omega}\right)
\end{array}
\end{aligned}
$$

This is the initial target REDOX 'REDOX (o $\left.m, \mathrm{~V}_{\mathrm{m}}, \mathrm{MO}^{\mathrm{M}} \mathrm{COOH}^{\mathrm{MO}} \mathrm{NO3}\right)=0.207$

The following additions can be made: $\quad \mathrm{mw}_{\mathrm{Cu}}:=63.54 \mathrm{gm} \cdot \mathrm{mo}^{\prime} \quad \mathrm{mw}_{\mathrm{H} 2 \mathrm{O}}:=18.0154 \mathrm{gm} \cdot \mathrm{mor} \Gamma^{1} \quad \mathrm{mw}_{\mathrm{NO}}:=(14.007+3 \cdot 15.9994) \cdot \mathrm{gm} \cdot \mathrm{mor}^{1}$

$$
\begin{array}{llllll}
\mathrm{Cu}\left(\mathrm{NO}_{3}\right) \cdot 3\left(\mathrm{H}_{2} \mathrm{O}\right) & \mathrm{m}_{1}:=0.6181 \cdot \mathrm{gm} & \mathrm{mw}_{1}:=\mathrm{mw}_{\mathrm{Cu}}+2 \cdot \mathrm{mw}_{\mathrm{NO}}+3 \cdot \mathrm{mw}_{\mathrm{H} 2 \mathrm{O}} & \mathrm{M}_{1}:=\mathrm{m}_{1} \cdot \mathrm{mw}_{1}{ }^{-1} & \mathrm{M}_{1}=2.55810^{-3} \mathrm{~mol} \\
50 \%(10.20 \mathrm{M}) \mathrm{HNG} & \mathrm{V}_{2}:=\frac{0}{1.299} \cdot \mathrm{mL} & \mathrm{mw}_{2}:=(1.008+14.007+3 \cdot 15.9994) \cdot \mathrm{gm} \cdot \mathrm{moI}^{-1} & \rho_{2}:=1.299 \mathrm{gm} \cdot \mathrm{mL}^{-1} & \mathrm{~m}_{2}:=\rho_{2} \cdot \mathrm{V}_{2} \quad \mathrm{~m}_{2}=0 \cdot \mathrm{gm} \\
\text { sucrose }\left(\mathrm{C}_{12} \mathrm{H}_{22} \mathrm{O}_{11}\right) & \mathrm{m}_{3}:=0.5754 \mathrm{gm} & \mathrm{mw}_{3}:=(12 \cdot 12.01115+22 \cdot 1.008+11 \cdot 15.9994) \frac{\mathrm{gm}}{\mathrm{mol}} & \mathrm{M}_{3}:=\mathrm{m}_{3} \cdot \mathrm{mw}_{3}^{-1} & \mathrm{M}_{3}=1.681 \cdot 10^{-3} \mathrm{~mol}
\end{array}
$$

The contributions from the above additions are:

$$
\begin{aligned}
& \text { I: } \mathrm{ml}_{\mathrm{Cu}}:=\mathrm{M}_{1}{ }^{-\mathrm{mw}} \mathrm{Cu}_{\mathrm{s}} \quad \mathrm{ml}_{\mathrm{Cu}}=0.163 \mathrm{gm} \quad \mathrm{Ml}_{\mathrm{NO}}:=2 \cdot \mathrm{M}_{1} \quad \mathrm{Ml}_{\mathrm{NO}}=5.117 \cdot 10^{-3} \mathrm{~mol} \\
& \mathrm{ml}_{\mathrm{H} 2 \mathrm{O}}:=3 \cdot \mathrm{M}_{1} \cdot \mathrm{mw}_{\mathrm{H} 2 \mathrm{O}} \quad \mathrm{ml}_{\mathrm{H} 2 \mathrm{O}}=0.138 \mathrm{gm} \\
& \text { 2: } \mathrm{M}_{\mathrm{HNO}}:=10.20 \mathrm{~mol}^{-1} \cdot \mathrm{L}^{-1} \cdot \mathrm{V}_{2} \quad \mathrm{M}_{2} \mathrm{HNO}_{3}=0 \mathrm{~mol} \quad \mathrm{M}^{2} \mathrm{NO}_{3}:=\mathrm{M} 2 \mathrm{HNO} \quad \mathrm{M}_{2} \mathrm{NO}=0 \mathrm{~mol} \\
& \mathrm{~m}^{2} \mathrm{HNO}_{3}:=\mathrm{M}_{2} \mathrm{HNO}^{-\mathrm{mw}_{2}} \quad \mathrm{~m}^{2} \mathrm{HNO}_{3}=0 \mathrm{gm} \quad \mathrm{m}^{2} \mathrm{H}_{20}:=m_{2}-\mathrm{m}^{2} \mathrm{HNO}_{3} \quad \mathrm{~m}_{2} \mathrm{H} 2 \mathrm{O}=0 \mathrm{mgm} \\
& \text { 3: } \mathrm{M}^{3} \mathrm{C}:=12 \cdot \mathrm{M}_{3} \quad \mathrm{M}^{3} \mathrm{C}=0.02 \mathrm{~mol} \quad{ }^{\mathrm{M} 0} \mathrm{COOH}^{=0.021 \mathrm{~mol}}
\end{aligned}
$$

The final SME material will have the following properties:

$$
\begin{aligned}
& \text { Final mass: } \quad m_{f}:=m_{0}+m_{1}+m_{2}+m_{3} \quad m_{f}=41.35 \% g m \\
& \text { Approximate volume: } \quad V_{f}:=V_{m}+V_{2} \quad V_{f}=30.567 \mathrm{~mL} \quad P_{f}:=\frac{m_{f}}{V_{f}} \quad P_{f}=1.3530 \mathrm{gm} \cdot \mathrm{mL}^{-1}
\end{aligned}
$$

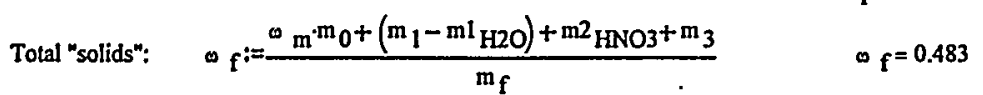

$$
\begin{aligned}
& \text { Calcined solids: } \quad c_{\mathrm{f}}:=\frac{c_{\mathrm{m}} \mathrm{m}_{0}+1.2518 \mathrm{ml} \mathrm{Cu}}{\mathrm{m}_{\mathrm{f}}} \quad c_{\mathrm{f}}=0.393 \quad \text { (assuming } \mathrm{Cu}_{\text {goes to }} \mathrm{CuO} \text { ) }
\end{aligned}
$$

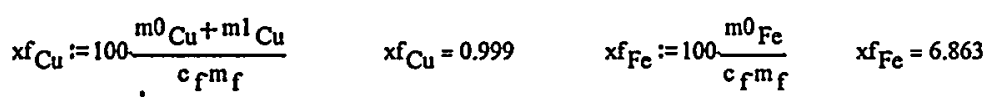

$$
\begin{aligned}
& \mathrm{Mf}_{\mathrm{COOH}}:=\mathrm{M0} \mathrm{COOH}^{+2 \cdot \mathrm{M} 3} \mathrm{C} \quad \quad \mathrm{Mf}_{\mathrm{COOH}}=0.062 \mathrm{~mol} \\
& \mathrm{Mf}_{\mathrm{NO} 3}:=\mathrm{MO}_{\mathrm{NO} 3}+\mathrm{M1}_{\mathrm{NO} 3}+\mathrm{M} 2 \mathrm{NO} 3 \quad \mathrm{Mf}_{\mathrm{NO} 3}=0.013 \mathrm{~mol}
\end{aligned}
$$

$$
\text { Checked by: W. E. Daniel G. E1 , Date: 28-99 }
$$

